$$
\begin{aligned}
& \text { الآثار المحتملة من تطبيق معيار التقارير المالية (IFRS9) } \\
& \text { على أنظمة المعلومات المصرفية }
\end{aligned}
$$

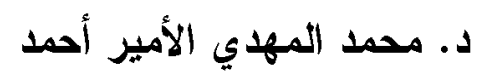

$$
\begin{aligned}
& \text { أستاذ المحاسبة المساعد الماند } \\
& \text { كلية العلوم الإدارية جامعة أم درمان الإسلامية } \\
& \text { المستخلص: } \\
& \text { تهدف الدراسة لتحليل الآثار المحتملة من تطبيق معيار التقــارير الماليــة الــدولي } \\
& \text { على أنظمة المعلومات المصرفية في القطاع المصرفي السوداني، وتناولــــ (IFRS9) }
\end{aligned}
$$

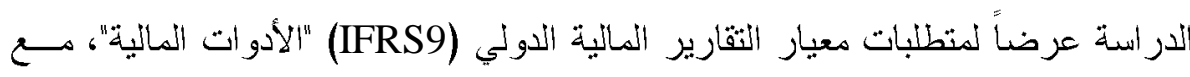

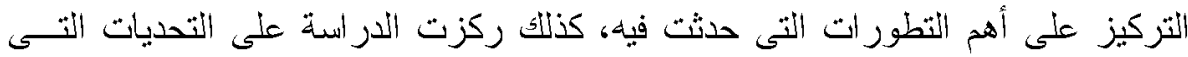

$$
\begin{aligned}
& \text { تواجه القطاع المصرفي النسوداني عند الإنتقال للتطبيق الفعلي لمتطنبات (IFRS9) فــي } \\
& \text { تصنيف وقياس الأدوات المـالية، وتوصلت الدر اسة إلى مجموعة من النتائج أهمها: أُتــر }
\end{aligned}
$$

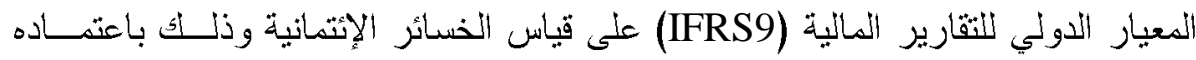

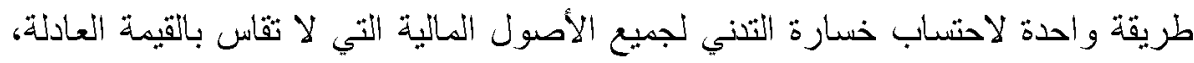

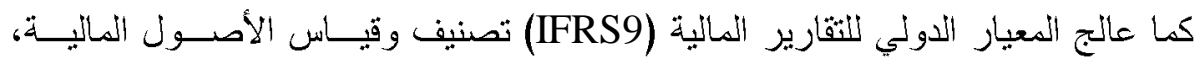

$$
\begin{aligned}
& \text { بالإضدافة لبعض التوصيات. } \\
& \text { الكلمات المفتاحية: IFRS9 - أنظمة المعلومات المصرفية - القطاع المصرفي. }
\end{aligned}
$$

Abstract

The study aims at analyzing the probable consequences of applying the (IFRS9) on Sudanese banking information system, so the study addressed presentation of the (IFRS9) requirements (financial instruments) ,focusing on important development occurring in it ,and focusing on the challenges that faced Sudanese banking sector upon transformation of actual applying for (IFRS9 requirements) in classifying and measuring the financial instruments ,The study reached important some results such as the impact of (IFRS9) on measuring the credit losses relying on one method to calculate the loss and the impairment of financial assets which can't be measured by the fair value, the (IFRS9) also treats the classification and measurements the financial assets in addition to some recommendations.

The key words: IFRS9- banking information systems- banking sector 


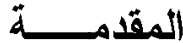

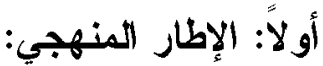

- تمهيد:

ألقت الأزمة المالية العالمية الضوء على العديد من نقاط الضعف المتعلقة بنطبيـق

محاسبة القيمة العادلة على الالتزامات المالية، فقد أظهرت مدى الارتباط بين الاقتصـاد الكلي و الأسواق المالية، كما نبهت إلى ضرورة وجود معاييز محاسبية مقبولة قبو لاً عاماً وذات مستوي رفيع، وبصفة خاصدة فيما يتعلق بالمعالجة المحاسبية للأدو ات المانية، كمــا

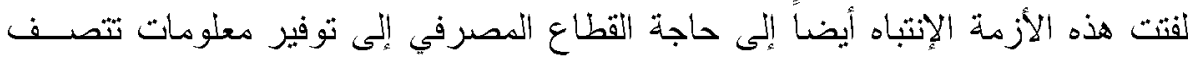
بالموثوقية تفيد في بيان العلافة مع المخاطر الناتجة عن المعاملات الخاصــة بـالأدوات التهات المالية، ونتيجة لذلك فقد صدر معيار التقارير المائية (IFRS9) هو معيار بتتاول المعالجة المحاسبية للأدوات المالية وقد جاء ليحل محل معيار المحاسبة الدولي رقم (9) (ب).

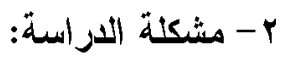

نتيجة للمشكلات التى واجهت القطاع المصرفي عن تطبيق وقيــاس الأســتئـار ات

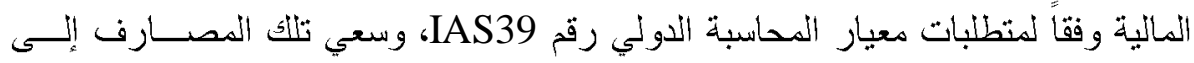
تحسبن المحاسبة عن الأدوات المالية وعلى الأخص محاسبة الاستثمار ات المانية، إتجهت

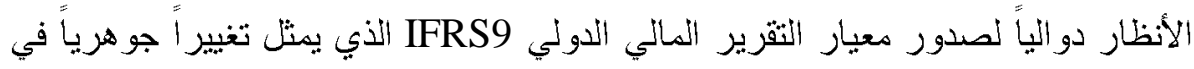

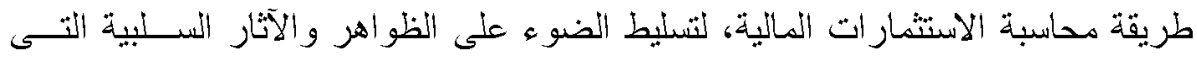

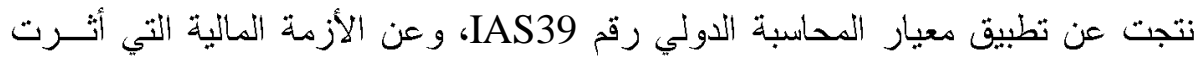

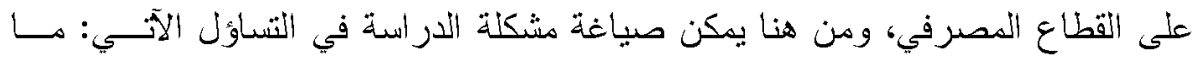

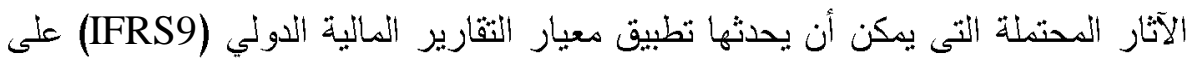

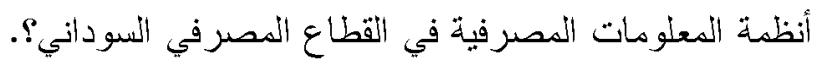

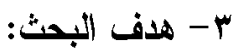

يتمثل الهدف العام للبحث في بيان الآثار المحتملة من تطبيق معيار التثارير المالية

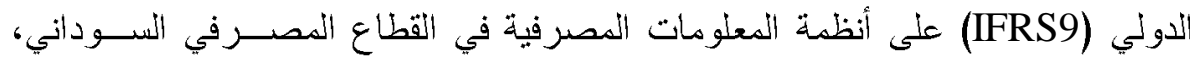
ويمكن تحقيق هذا الهذف من خلال تحقيق الأهداف الفرعية التالية:

أ- عرض وتحليل منطلبات معيار التقارير المالية الدولي (IFRS9) "الأدوات المالية".

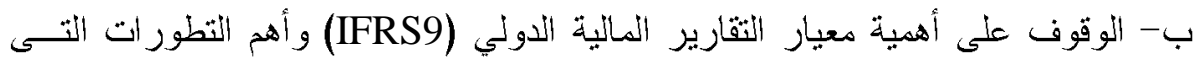
حدثت فيه. 
ج- القيام بدر اسدة ميدانية في القطاع المصدفي السوداني لدر استة أثز معيار التثارير المالية الدولي (IFRS9) على أنظمة المعلومات المصرفية. د- التعرف على التحديات التى نتواجه القطاع المصرفي السوداني عند الإنتقال للتطبيـقن الفعلي لمنطلبات IFRS9 في تصنيف وقياس الأدوات المالية. ـ - أهمية البحث:

تستمد الدر استة أهميتها من كونها تتاولت أحد الموضو عات المعاصرة فـــي الفكــر

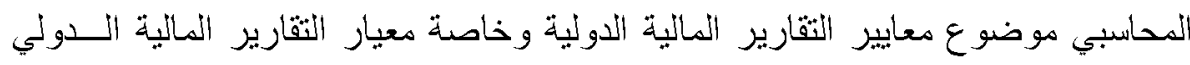

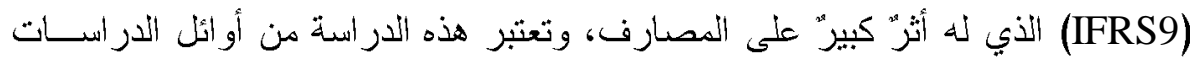

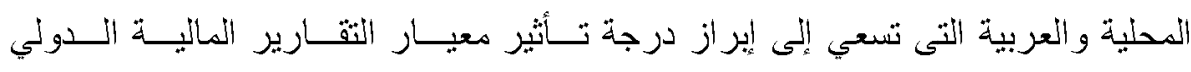
(IFRS9)

$$
\text { ه - فرضيات البحث: }
$$

في ضوء مشكلة البحث المطروحة و الأهداف التىى بسعي (الباحث) إلى تحقيقها تـــ وضع الفروض التالية للعمل على اختبارها وتحقيق الأهداف المرجوة منها: أ- الفرضية الأولي: توجد علاقة معنوية بين تطبيق منطلبات تصنيف وقياس الأدوات

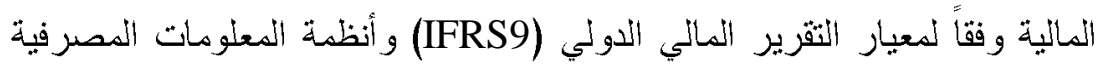
في القطاع المصرفي النسوداني.

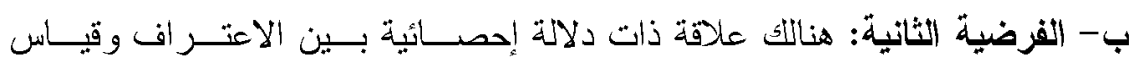

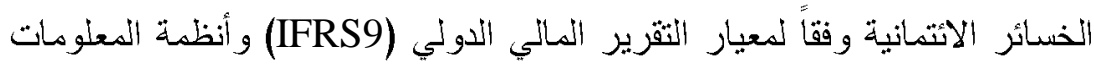
المصرفية في القطاع المصرفي السوداني. ج- الفرضية الثاثثة: توجد علاقة ارتباط بين الاثتمان الذاتي وفقاً لمعيـــر التثريــر

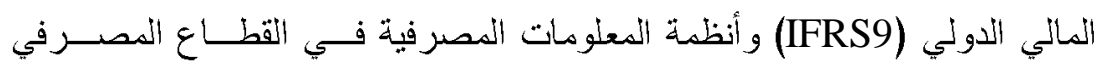
السوداني. د- الفرضية الرابعة: نوجد علاقة تأثير ذات دلالة معنوية بين نطبيق متطلبات

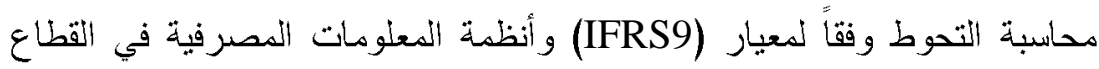
المصرفي السوداني. 
لتحقيق أهداف الدراسة اتبع (الباحث) مجموعة من مناهج البحث العلمي تحقق فيما

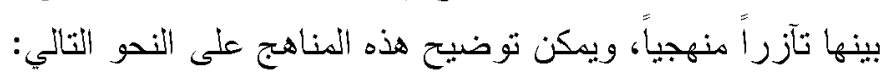
أ- المنهج الاستتباطي: الأبي يعتمد على التفكير المنطقي وقد اعتمد عليه (الباحث) فـي فئي

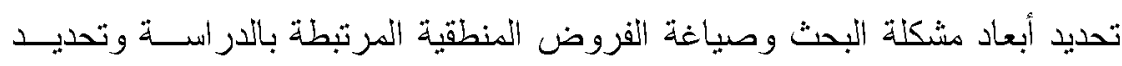
المحاور الأساسية للبحث. ب- المنهج التاريخي: اعتد عليه (الباحث) في عرض وتحليـلـل الدراســات الســابقة المرتبطة بمجال الدر استة. ج- المنهج الاستثر ائي: وقد اعتمد عليه (الباحث) في إثبات مدى صحدة الفرضيات.

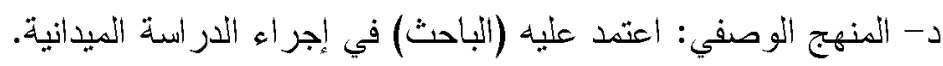

$$
\text { - V }
$$

تتحدد نتائج هذا البحث باتحدود التالية:

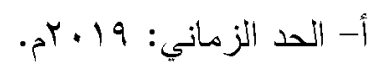

ب- الحد البشري: يتكون من المر اجعين الداخلين، المــدراء المـاليين، مــدراء ادارة

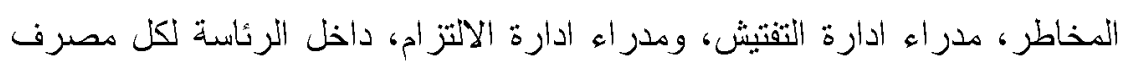

$$
\text { من المصارف عينة الدراسة. }
$$

$$
\text { ج- الحد المكاني: القطاع المصرفي السوداني. لدرنه }
$$

د- الحد الموضوعي: يقتصر على بيان الآثار المحتملة من تطبيق معيار التقارير المالية

$$
\text { الدولي (IFRS9) على أنظمة المعلومات المصرفية. }
$$

$$
\text { - م- نموذج الدراسة: }
$$

اعتماداً على ما ورد في الدراسدات السـابقة، وانسجاماً مع أهداف الدراسة وشــــها، فقد تمت صياغة نموذج يمنل متغير ات الدر است، وفيما يلي توضيح لهذا النموذج من خلا وله

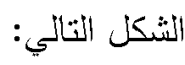




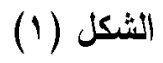

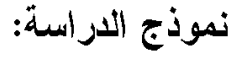

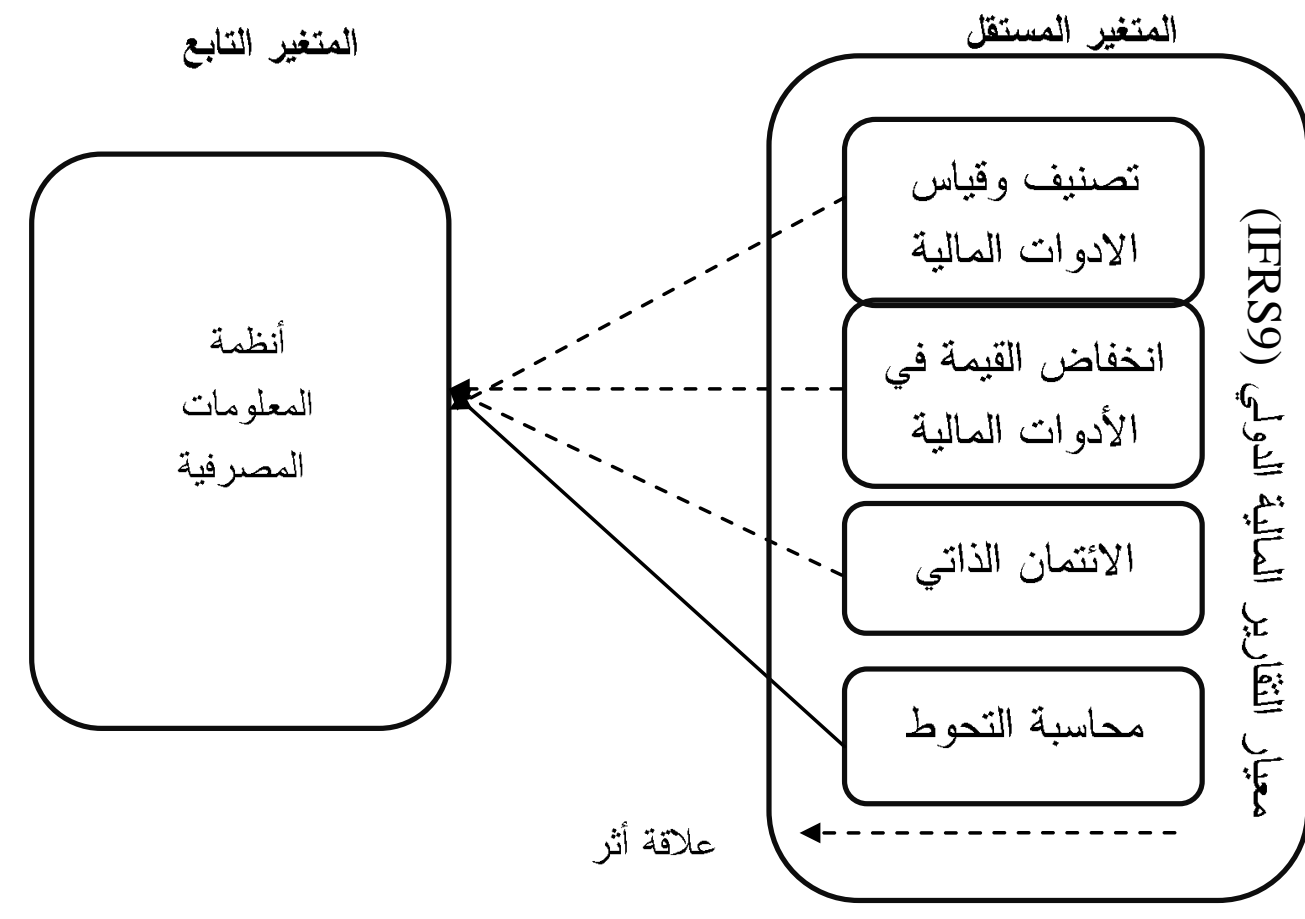

المصدر: إعداد (الباحث) بالاستفادة من الأدبيات، 11 • بَم.

$$
\text { ف - خطة البحث: }
$$

في ضوء منهجية البحث وتحقيقاً لأهدافه، تم تقسيم خطة هذه الدراسة على النحو التنالي:

المقدمة: تشتثل على الإطار الكنهجي و الأر اسات السابقة.

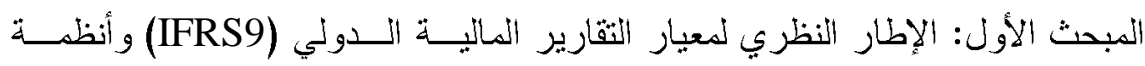

$$
\begin{aligned}
& \text { المعلومات المصرفية. } \\
& \text { المبحث الثاني: الدراسة الميدانية. } \\
& \text { الخاتدة: تتثنل على النتائج و التوصيات. } \\
& \text { المصادر و المر اجع و الملاحق. } \\
& \text { ثانياً: الدراسات السابقة: }
\end{aligned}
$$

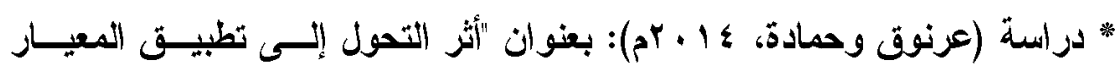

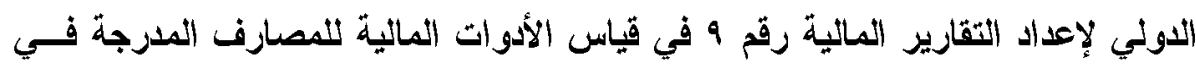

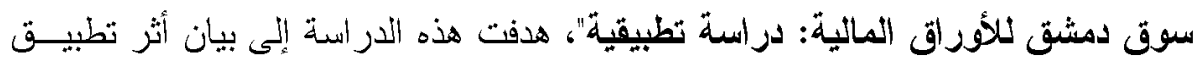


المعياز (IFRS9) "التصنيف و القياس" من قبل المصدارف المدرجة فـي ســوق دمثــق

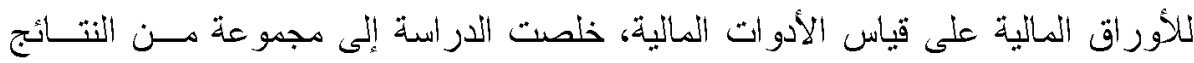

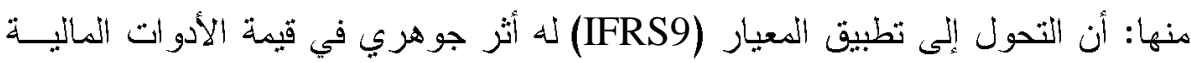

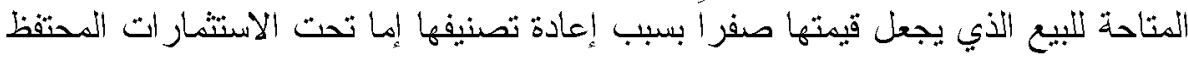
بها للمتاجرة أو تحت الاستثمار ات المتحفظ بها حتى تاريخ الاستحقاق.

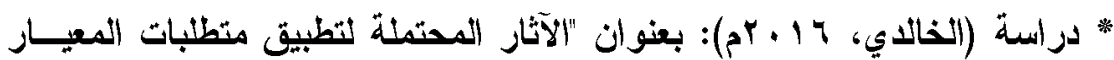
الاولي لإعداد التقارير المالية رثم 9 (إخفاض الخسائز الاتمانية المتوقعة) على البنوك

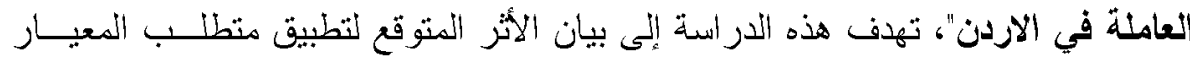

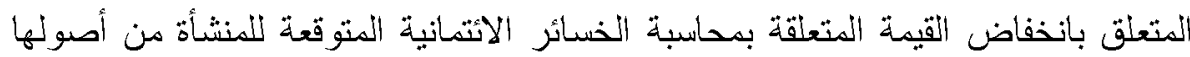

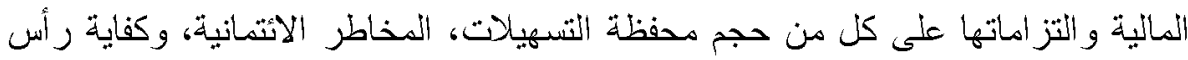

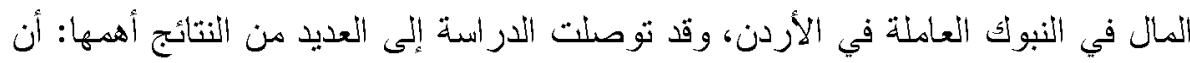

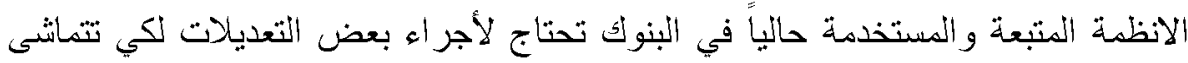

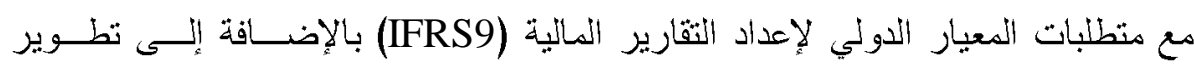
خبر ات الموظفين الحاليين ورفد البنوك بخبرات لتنتاسب مع متطلبات تطبيق المعيار .

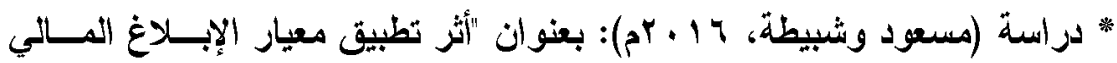

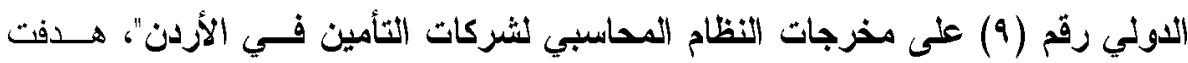

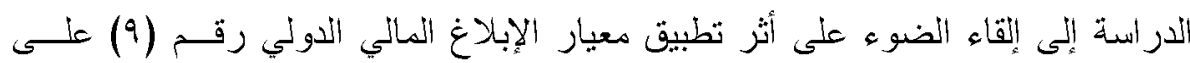

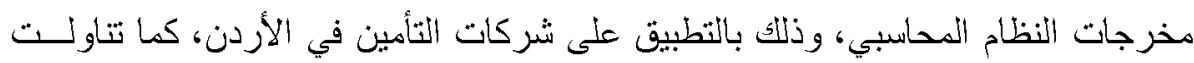
ستة عو امل رئيسية تعكس مخرجات النظام المحاسبي وهي ملاعمة المعلومات المحاسبية،

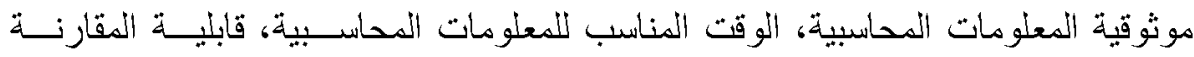

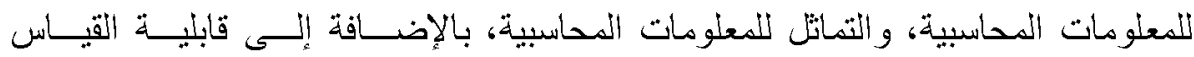
للمعلومات المحاسبية، وتوصلت الذر اسة إلى مجموعة من النتائج منها: يوجد أثر ذو دلالة إحصائية لتطبيق معيار الإبلاغ المالي الدولي رقم (9) على ملاعمة المعلومات المحاسبية في القو ائم المالية لشركات التأمين بالأردن.

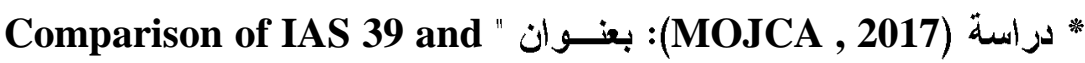

IFRS 9: The Analysis of Replacement معيار الثقارير المالية (IFRS9) على رأس المال للبنوك والمؤسسات المالية، وخلصــ

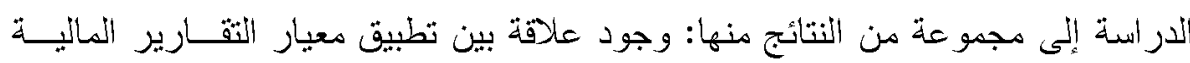


(القو اعد الرقابية للبنوك التى تعتمد على استخدام نموذج متطلبات رأس المال لمخاطر الاثتمان، كما تعاني البنوك عينة الدر استة من انخفاض سريع في رأس المال.

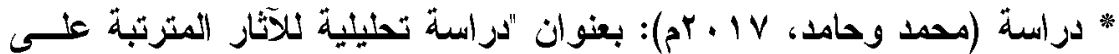

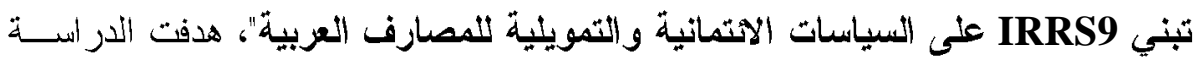
إلىى تحقيق هدف محوربي عام يتمثل في دراسة الآثار المتوقعة من تطبيق معيار التقارير

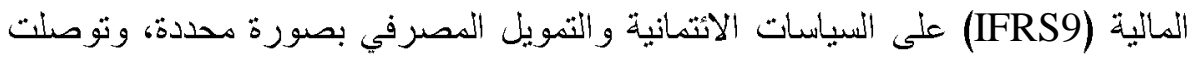

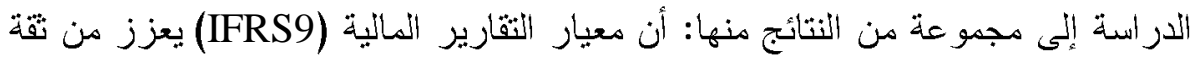

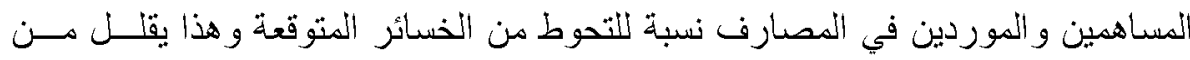
مخاطر السيولة وعلم الوفاء بالالتز امات.

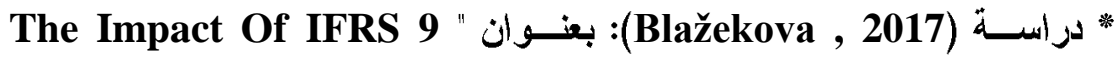
(increase in credit risk provisioning) on banks' regulatory capital (IFRS9) معيار التقارير المالية (IFRS9) ساهم في الحد من ظاهرة تضخم الخسارة الناتجة مــن

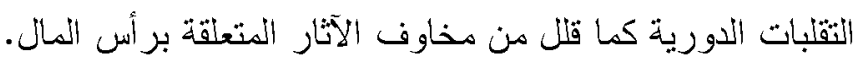

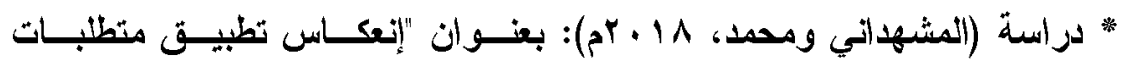
IFRS9

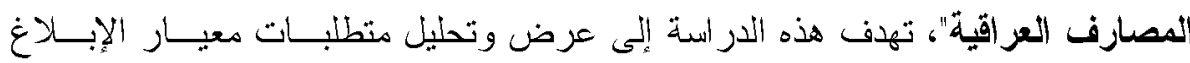
الدولي IFRS9(المالية) بشأن إنخفاض القيمة، فضلاً عن تطبيق تلأك المتطلبـات وبيــان

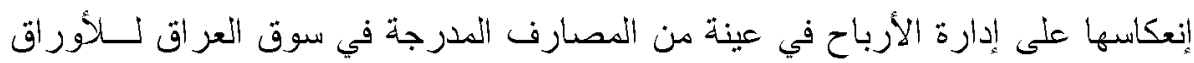

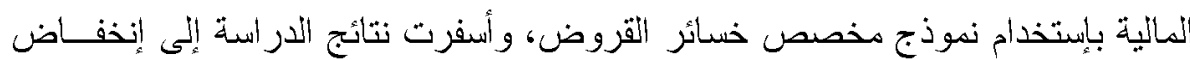
ممارسة إدارة الأرباح للمصدارف المدرجة في سوق العراق للأوراق المالية بعد تطبيـق

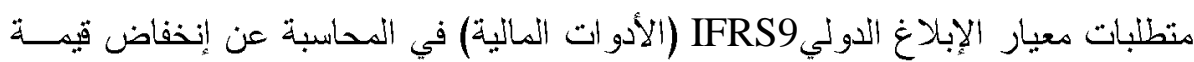
القزوض المصرفية.

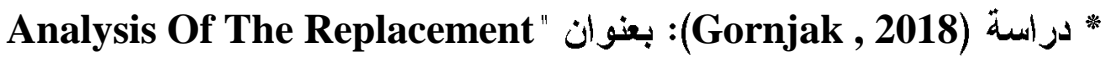
Of International Financial Reporting Standard For Financial Instruments: IAS 39 versus IFRS 9

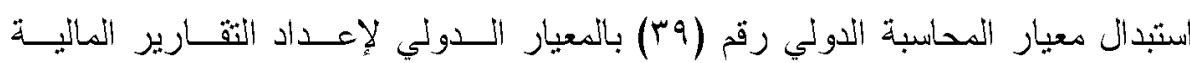

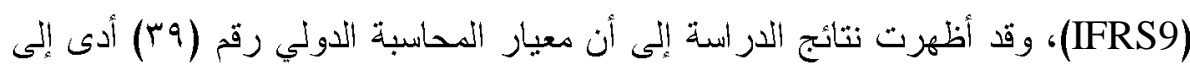


ظهور الازمة المالية عبر السماح بقدر أكبر من القروض والتوسع الآتـــاني وتحقيـق الأزباح غبر المحققة.

مناقثة الاراسات السابقة وما يميز الدراسة عن الدراسات السابقة:

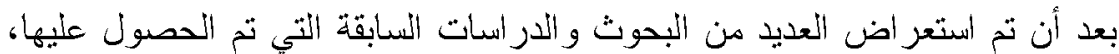
وفي ضوء ذلك بمكن الإثارة على الملاحظات الآتية:

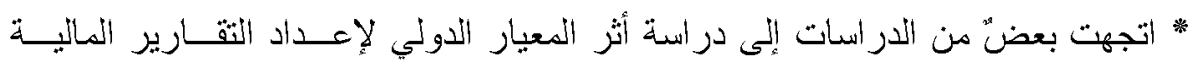

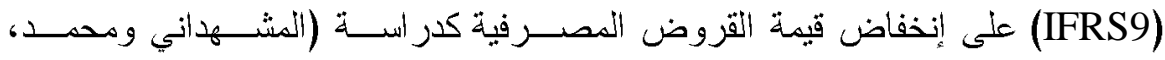

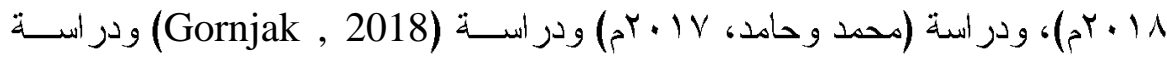

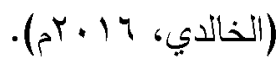
* القليل من الدر اسات تناولت دراسدة أنز المعيار الدولي لإعداد التقارير المالية (IFRS9)

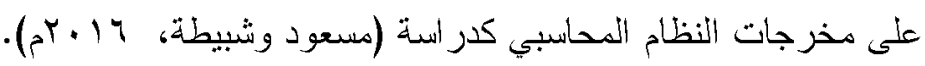

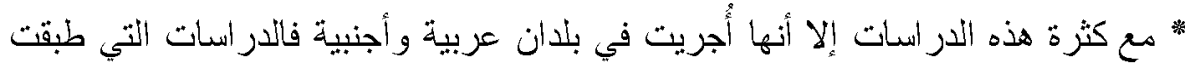

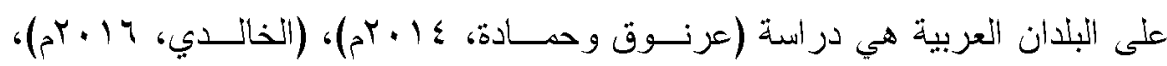

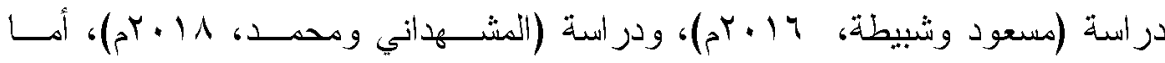

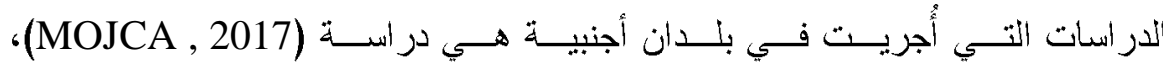

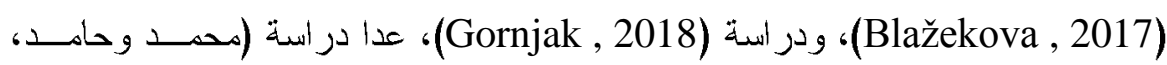

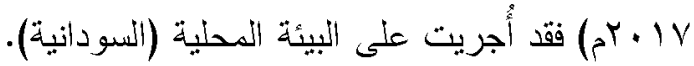
ما يميز الدراسة عن الدراسات السابقة: من خلال إستعر اض الار اسات السابقة ذات الصلة، بمكن تحديد ما تتميز به الأراسة الحالية عن الدراسات العابقة على النحو الثالي:تعتبر هذه الدر استة الأولي في السودان تناولت الآثار المحتملة من تطبيق معيـار

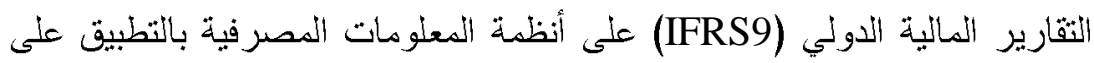
القطاع المصرفي السوداني، كما تمبزت أيضاً بحداثة فترة النطبيق.

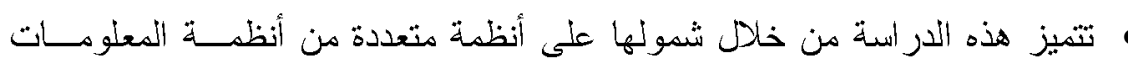
المصرفية كمتغير ات تابعة تتفرد بها. 
المبحث الأول: الإطار النظري للمعيار الدولي للتقارير المالية (IFRS9)

\section{وأنظمة المعلومات المصرفية المطرية}

أولاً: الإطار النظري للمعيار الدولي للتقارير المائية (IFRS9):

1- مفهوم ونشأة المعيار الدوني للثقارير المالية (IFRS9):

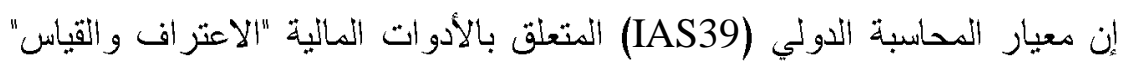

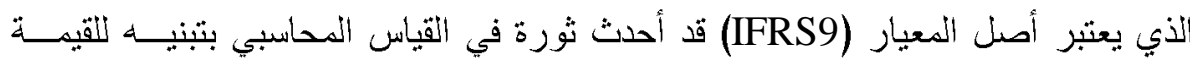

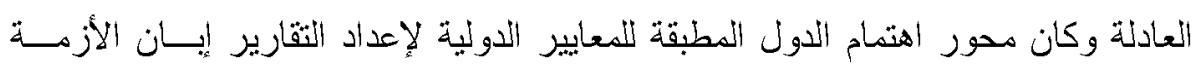

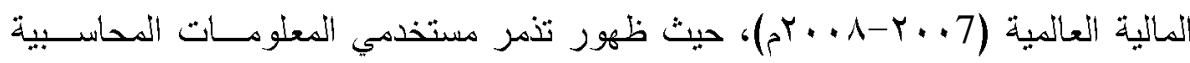

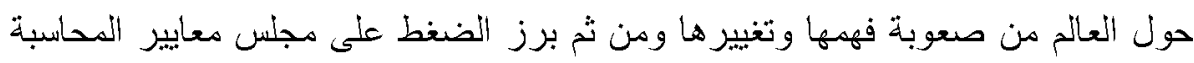

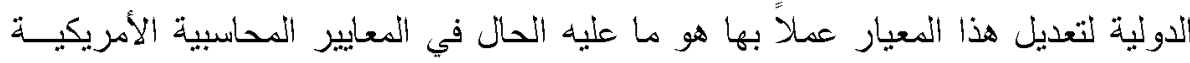

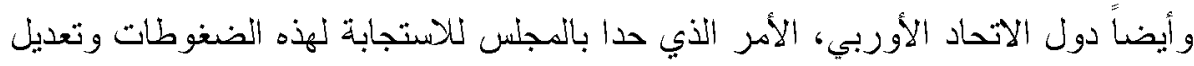

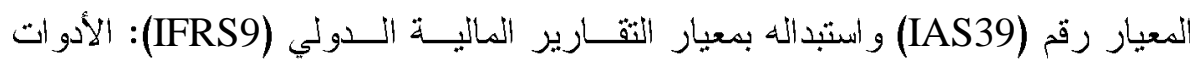

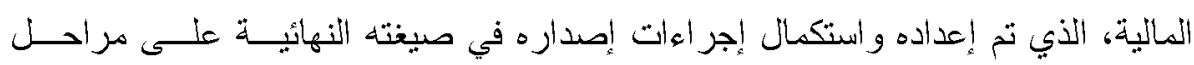

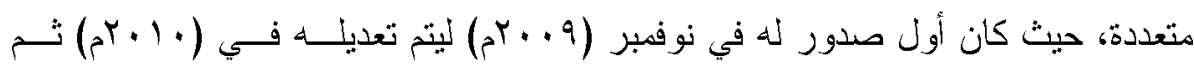

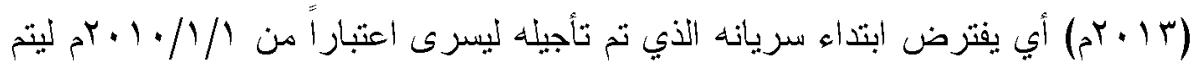

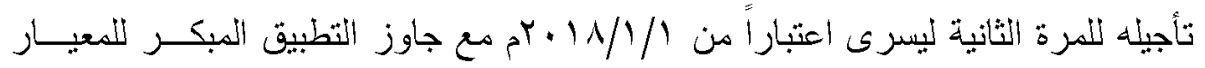

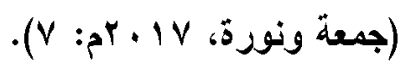

r- مراحل تطور المعيار الدوني للتقاريز المائية (IFRS9):

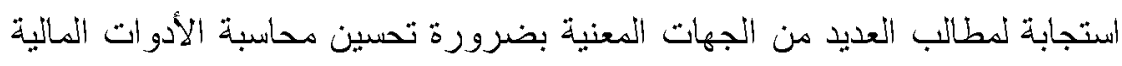

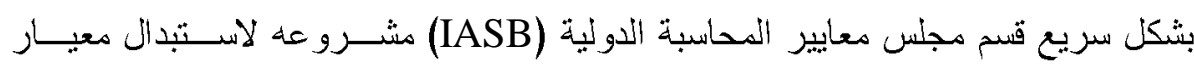

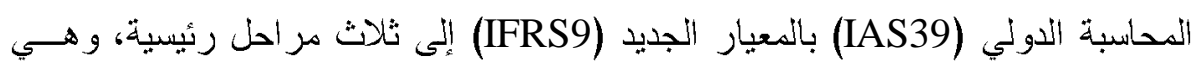

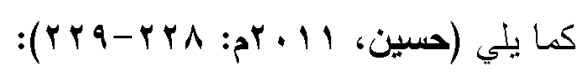

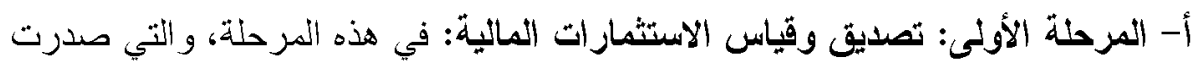

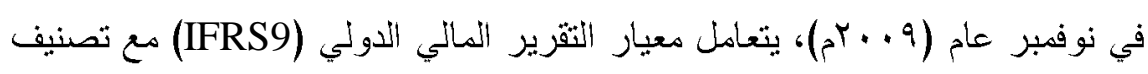

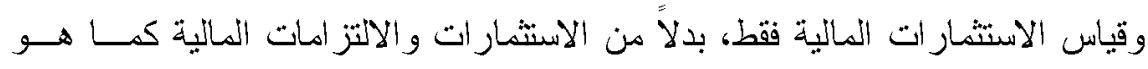

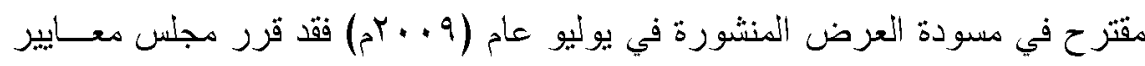

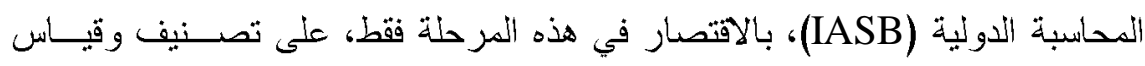

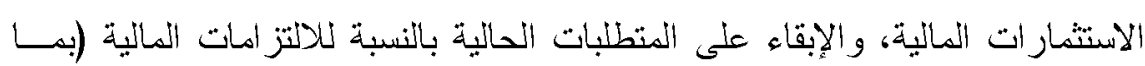

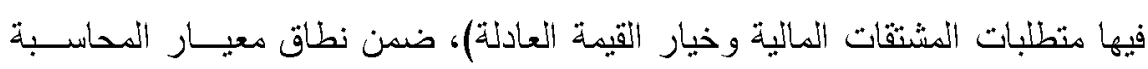




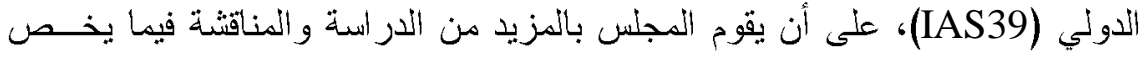

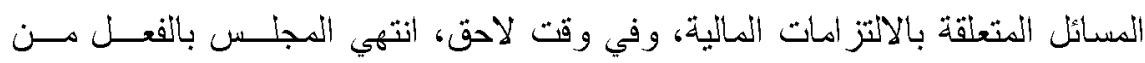
استكمال هذه المرحلة بإصدار متطلبات تصنيف وقياس الالتزامات المالية في أكتـوبر الكير

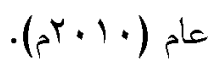
ب- المرحلة الثانية: منهجية انخفاض القيمة أو (المحاسبة عن الاضدحلا في القيمة)

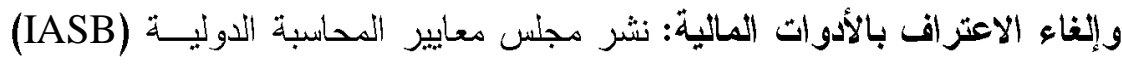

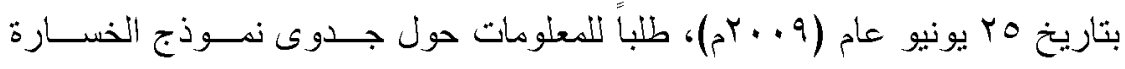

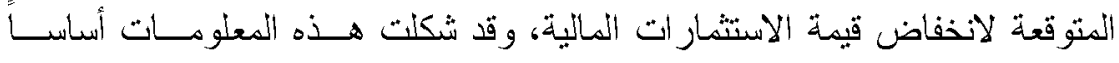

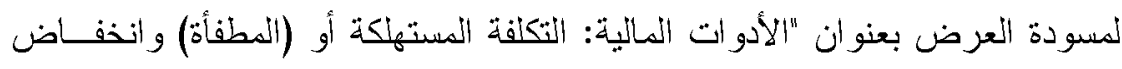

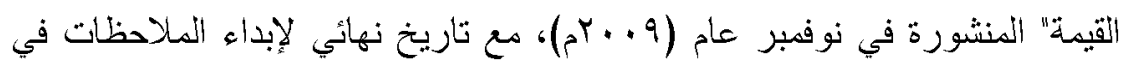

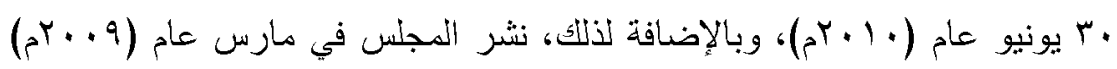

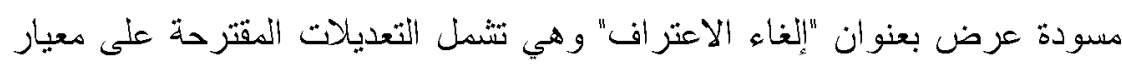

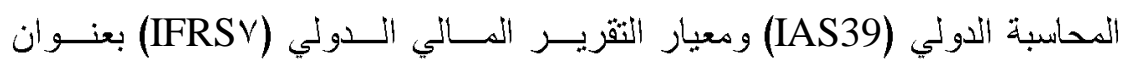

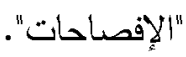

ج- المرحلة الثاثلة: محاسبة التغطية عن المخاطر (محاسبة التحوط): بدأ مجأسس

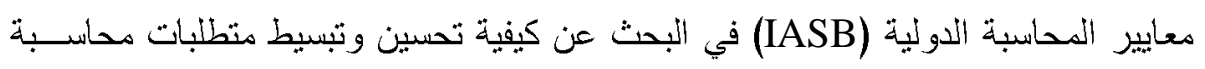

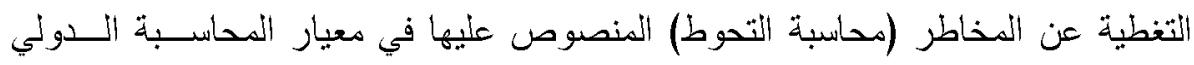

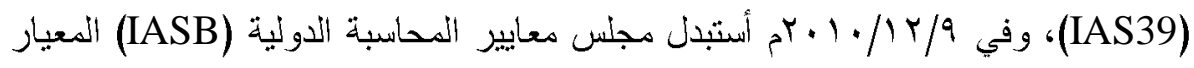

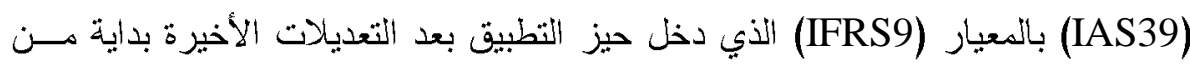

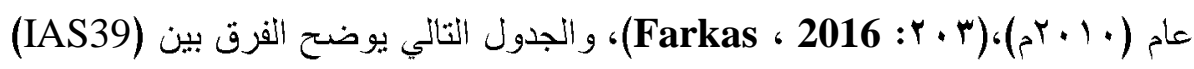
(IFRS9), 
الجدول: (1)

مقارنة بين (IAS39) و (IAS39) (IFRS9).

\begin{tabular}{|c|c|c|}
\hline IFRS9 & IAS39 & البيان \\
\hline فينتين & أصناف تصنيف الأصول المالية إلى أربعــة & التصنيف \\
\hline العنالكأك أصول يتم فياسها بالتكلفة & يتم القياس بالقيمة المعادلة & القباس \\
\hline تخضع لخسارة التبدني الأصول المالية الوحيدة التي & 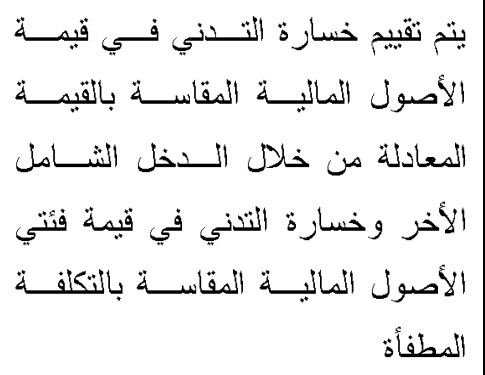 & خسارة تدني القيمة \\
\hline 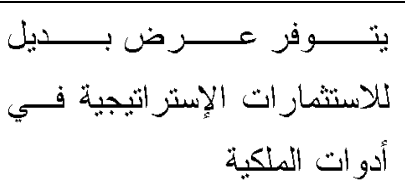 & 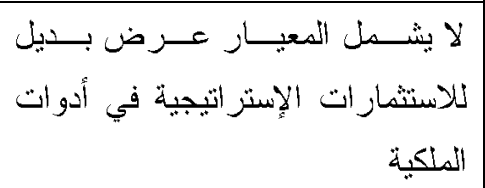 & 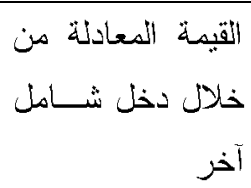 \\
\hline
\end{tabular}

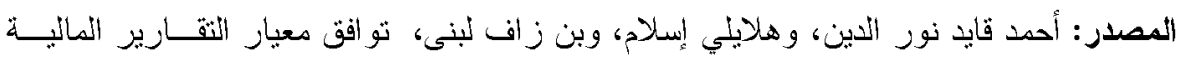

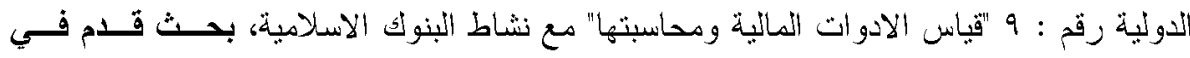

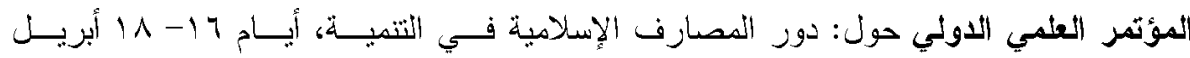

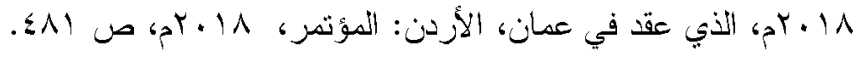

يلاحظ (الباحث) من خلال الجدول (1) أن هنالتك اختلافاً واضداً بــين المعيـارين ويمكن الإشارة إلى أوجه الخلاف من الآتي: من حيث التصنيف والقياس: يختلف المعيار (IFRS9) عن المعيار (IFS39) حيث نجد أن المعيار (IFRS9) يتضسن تصنيفاً جديداً

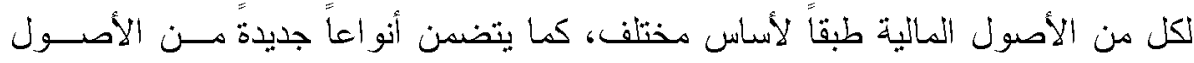

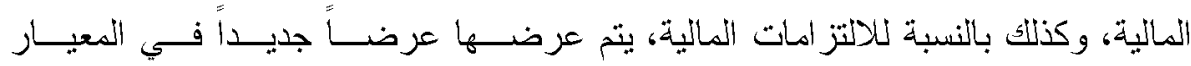
و لا يربط المعيار بين الاثتمان الذاتي والقيمة العادلة وذلك عن طريق الــدخل 
- أهداف ونطاق المعيار الدوني للتقارير المالية (IFRS9):

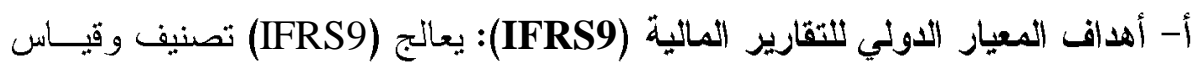

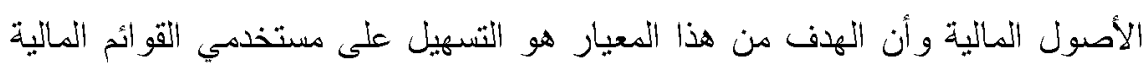

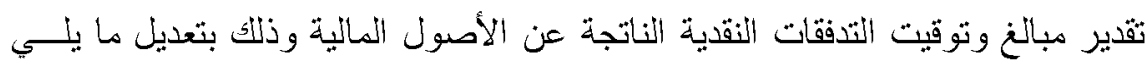

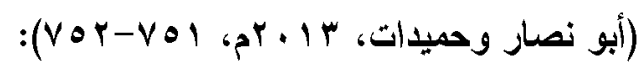

$$
\begin{aligned}
& \text { تخفيض عدد فئات التصنيف و القياس. }
\end{aligned}
$$

تحديد الأدوات المالية النتي يتم قياسها بالقيمة العادلة من خــلال الـــل الثنـامل

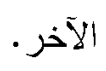

تحديد شروط تصنيف الأدوات بالتكلفة المطفأة. -III

شروط تغيير إعادة التصنيف في أدوات الاين من القيمة العادلة إلى التكلفة المطفأة

$$
\text { أو بالعكس. }
$$

- إلغاء المتطلبات المعقدة الموجودة بالمعيار (IAS39).

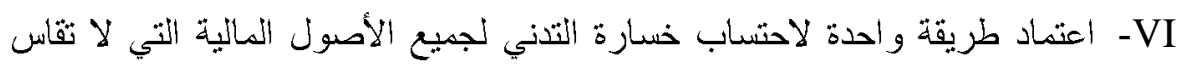

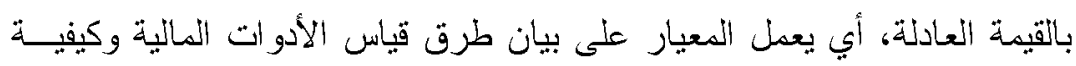

تصنيفها.

ب- نطاق المعيار الدولي للتقارير المالية (IFRS9): يشمل نطاق المعبـار (IFRS9)

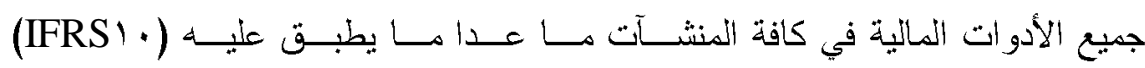
و (IAS27) و (IAS17) و (IAS28) و (IAS19)، ويدخل في نطاق هـذا المعيـار

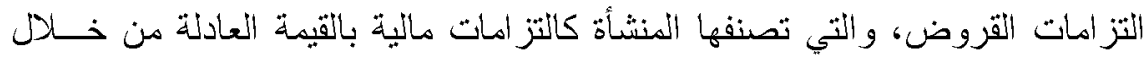

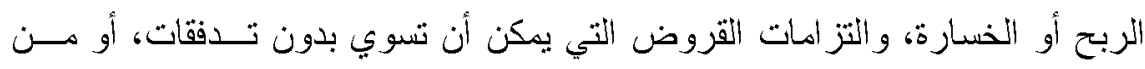

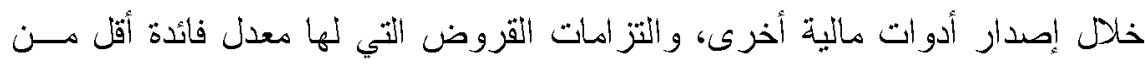

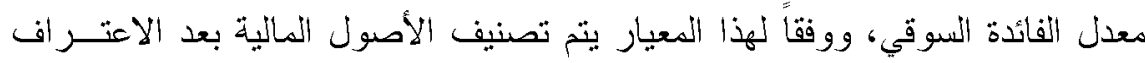

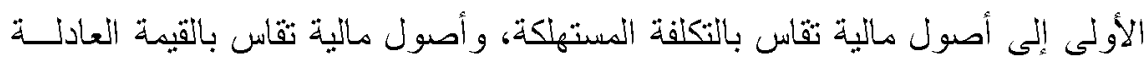

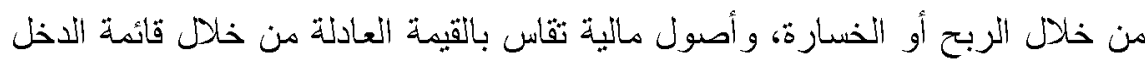

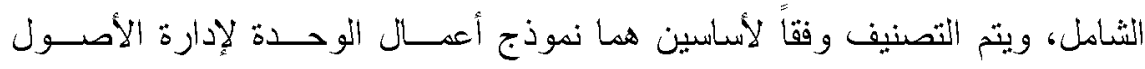

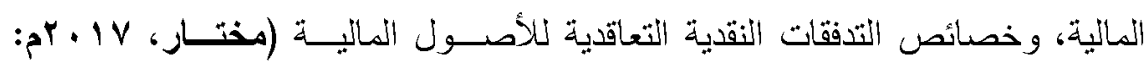
.$(1 \cdot 19-1 \cdot 11$

مما سبق يستتتج (الباحث) أن معيار التقرير المالي الدولي (IFRS9) جاء بعكس ما جاء به معيار المحاسبة الدولي (IAS39) حيث وفر مبرراً واضداً لقياس الاسـتئمارات 
المالية عبر مجموعة من التصنيفات وهي: الاستثمار ات المالية المقيمة بالقيمة العادلة من

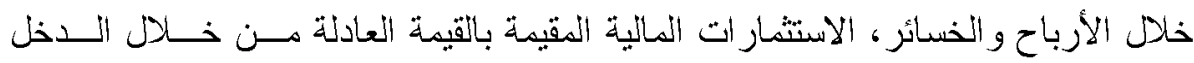
الثنامل الآخر ، والاستثمارات المالية المقيمة بالتكلفة المستهدفة، والتي يوضحها (الباحث) بشئ من التفصيل من خلال المحور التالي. ؛ - مضمون المعيار الاولي للتقاريز المالية (IFRS9):

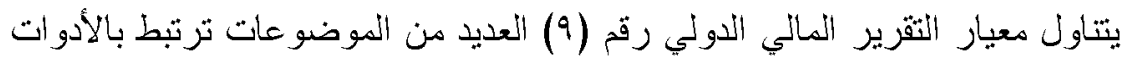
المالية، وكيفية معالجنها، ويتتاول (الباحث) أبرز مضامين هذا المعيار على النحو التـالي

$$
\text { (طارق، IV) }
$$

أ- التصنيف والقياس للأدوات المالية: يتبني معيار التثرير المـاني الــدولي (IFRS9)

منهجاً منطقياً لتصنيف وقياس الأصول المالية ويمكن توضيحه من خلال الآتي:

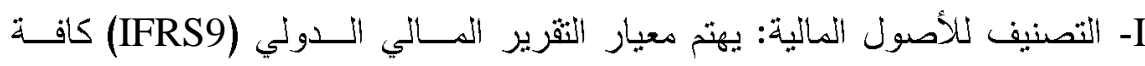
الأصول المالية إلى فئتين هما كالآتي: * الأصول المالية التي يتم قياسها (لاحقاً عند إعداد القوائم المالية) بالتكلفة المطفأة. * الأصول المالية المقاسة بالقيمة العادلة. ويمكن تصنيف الأصول المالية ضمن هذه الفئة إلى الآتي: - أصول مالية بالقيمة العادلة من خلال التربح أو الخسارة. - أصول مالية بالقيمة العادلة من خلال الاخل الثامل الآخر .

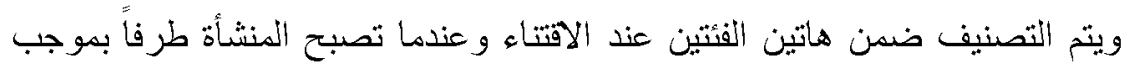

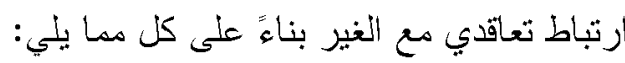

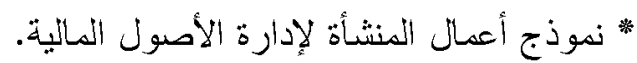

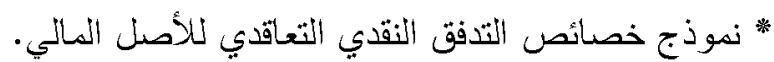

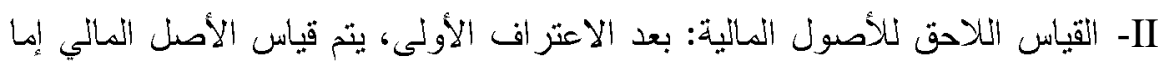
بالقيمة العادلة أو بالتكلفة المطفأة وفقاً لتصنيف الأصل المبدئي، ويتم ذلك من خلافل الأل

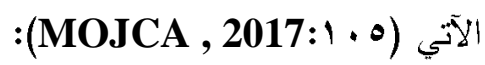

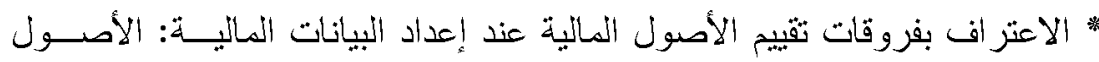

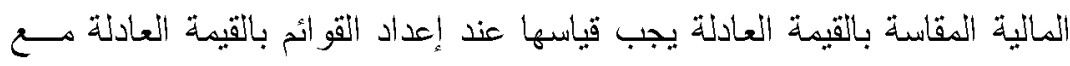

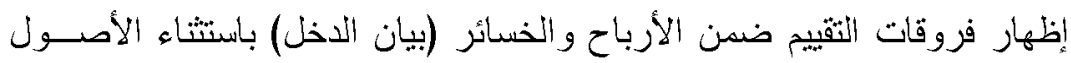

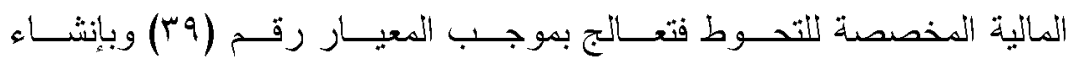

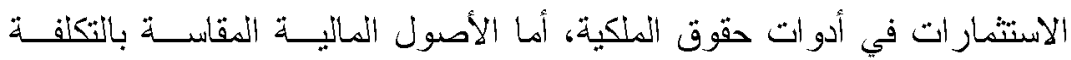

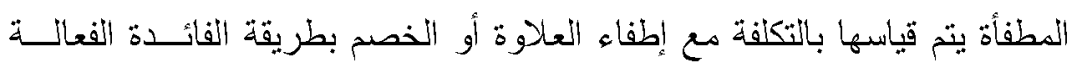




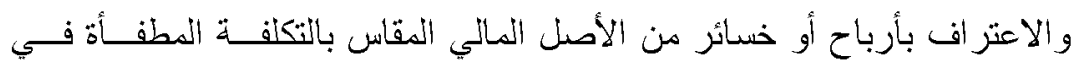

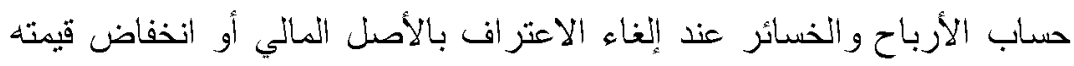
(تدني) أو إعادة تصنيفه.

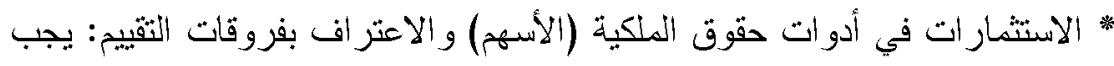

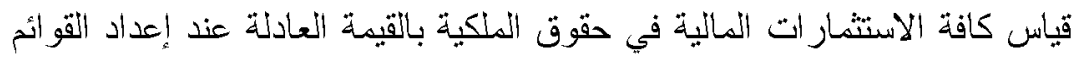

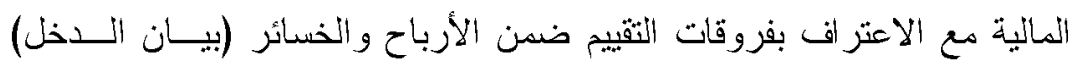

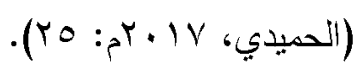

ب- انغفاض القيمة في الأدوات المالية: تضمن الإصدار النهاثي للمعيار رقم (IFRS9)

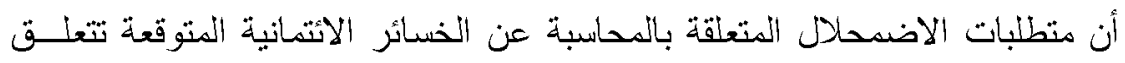

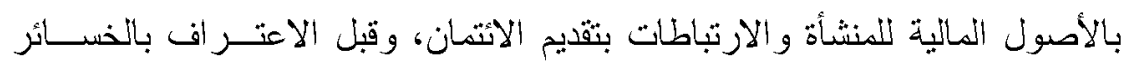

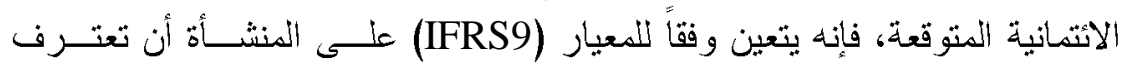

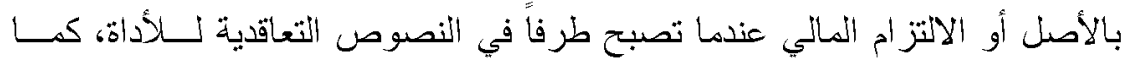

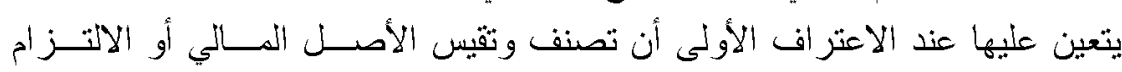

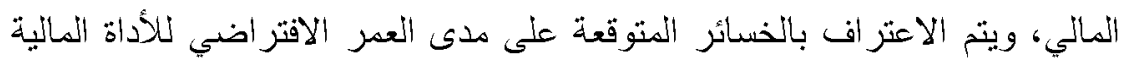

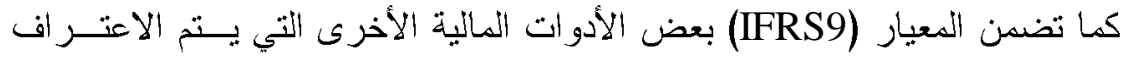

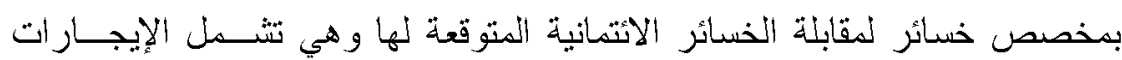

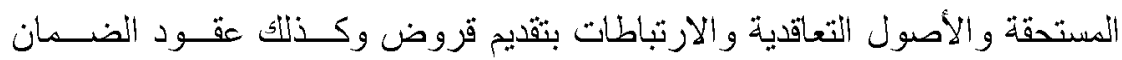

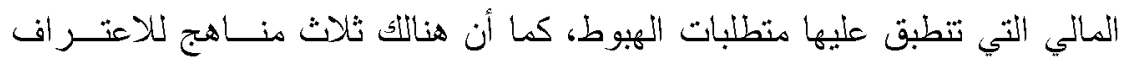

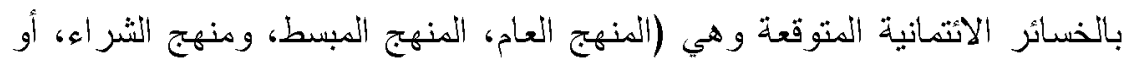

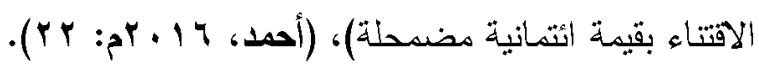

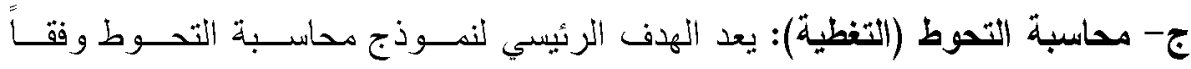

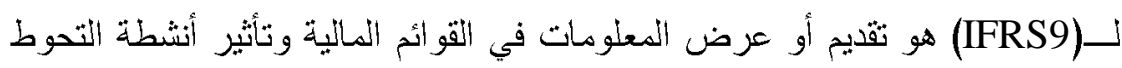

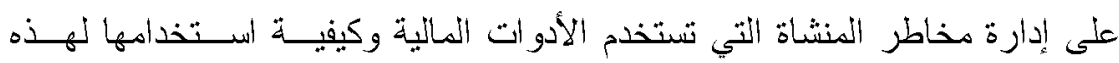

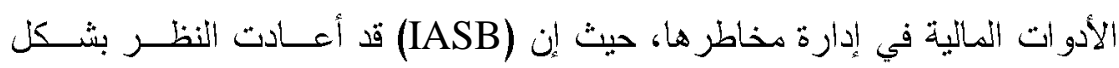

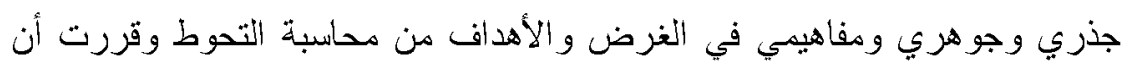

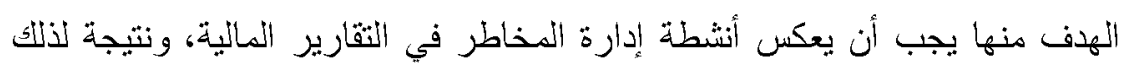

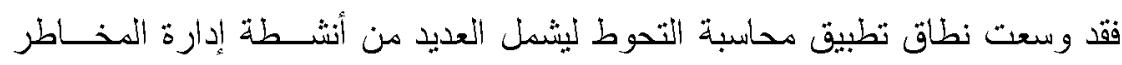

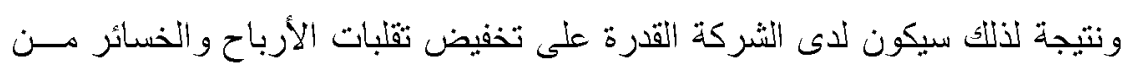

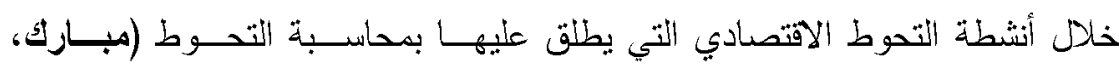


عموماً فمن خلال المعيار (IFRS9)، قام مجلس معايير المحاسبة الدولية بححاولــة تعديل الجوانب السلبية التي تم اكتثافها عند تبني وتطبيق المعايير ، فمن خلال هذا المعيار

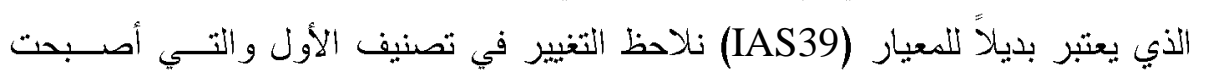

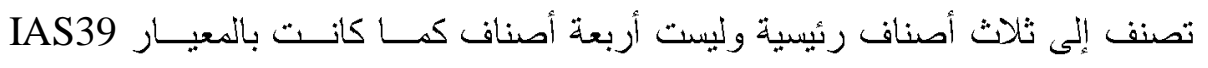

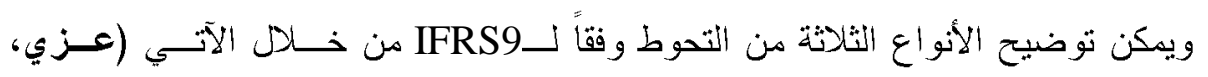
$:(r)$ T:P + Is

أ.تحوط القيمة العادلة: التحوط ضد مخاطر التغيرات في القيمة العادلة للأصل أو الالتزام

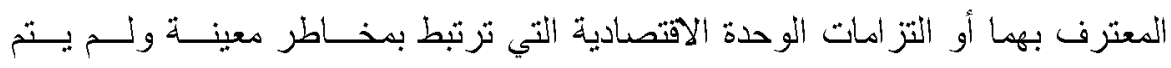

$$
\text { الاعتر اف بها. }
$$

تحوط التدفقات النقدية: التحوط ضد مخاطر التغيرات في التدققات النقدية للأصل -II أو الالتزام المعترف بهما أو عملية متوقعة ترتبط بمخاطر معينة.

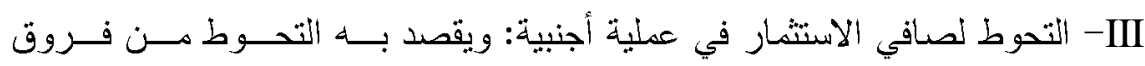

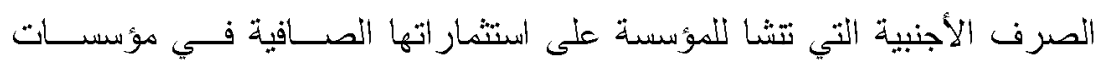

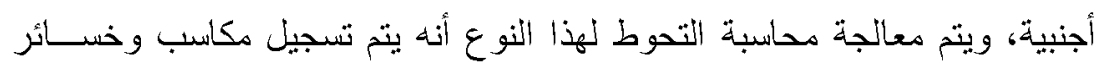
الصرف في رؤوس الأمو ال الخاصة ويوجد فرق طفيف في المعالجة يتعلق بما إذا وندا كانت أداة التحوط مشتقة أو غير مشتقة فإذا كانت الأداة غير مشتقة هنا عدم فعالية

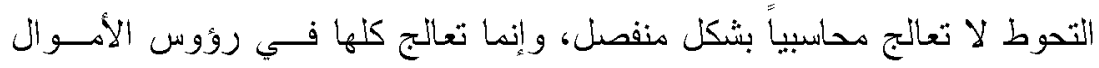

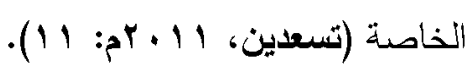

د- الاتمان الذاتي: يؤدى بتطبيق المعيار (IFRS9) إلى الحد من تقلبات الربح و الخسارة

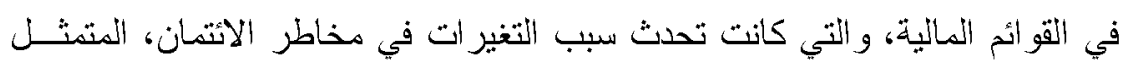

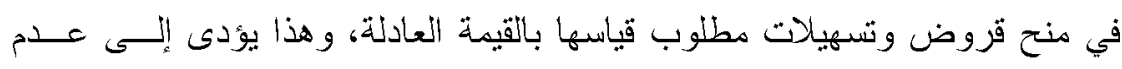

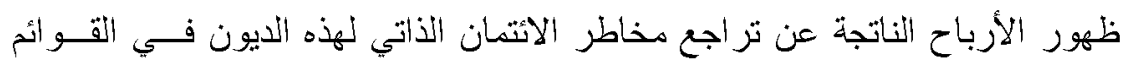

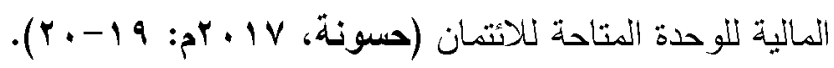

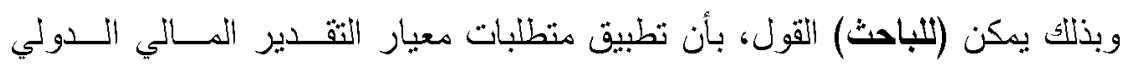

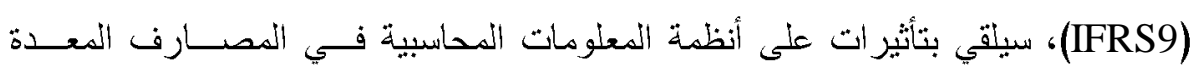

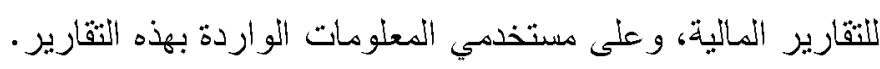
ه - التحديات التي تواجه تطبيق المعيار الدولي للتقاريز المالية (IFRS9):

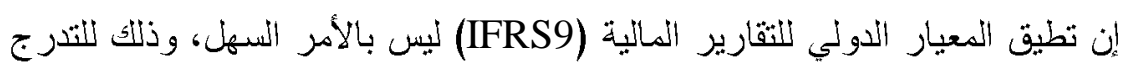

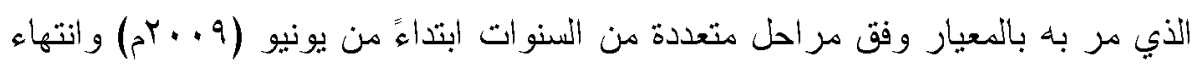




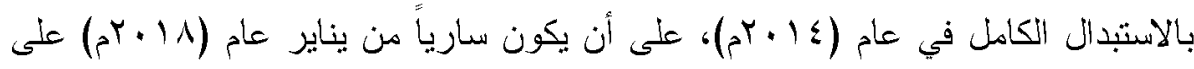

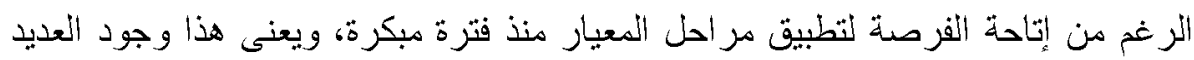

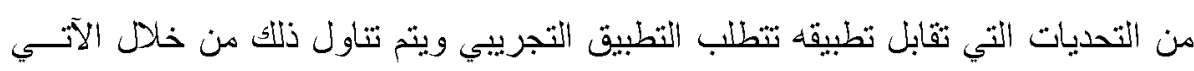

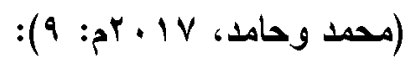

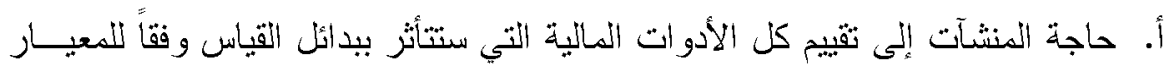

(IFRS9)

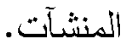

ب. وجود العديد من المجالات التي تتطلب الاجتهاد و التقسير من قبيل معدي البيانسات

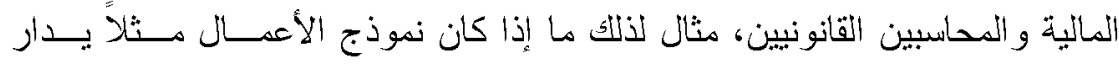
بطريقة نثطة بغرض تحقيق التغيير في القيمة العادلة.

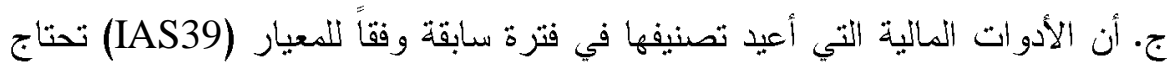

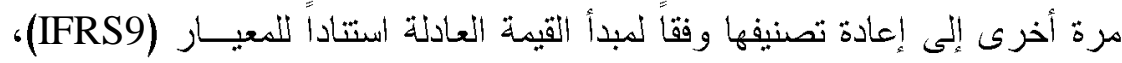

$$
\text { حيث إنها تعتد على نماذج الأعمال وخصائصها. }
$$

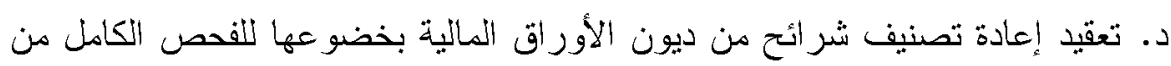

خالال النظر في مجموعة الموجودات.

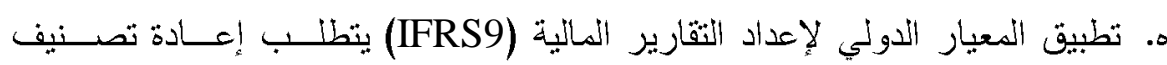

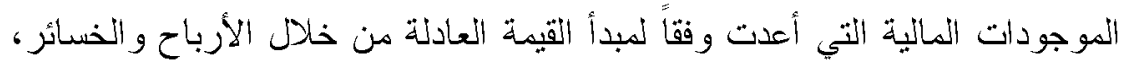

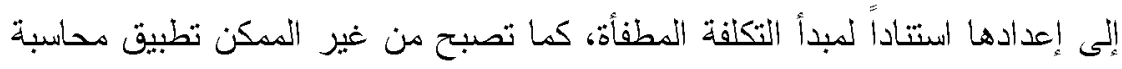

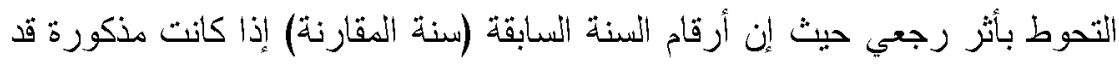

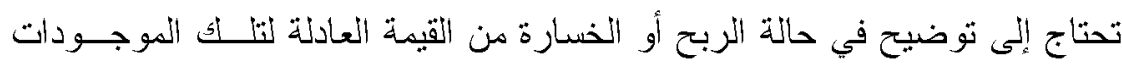

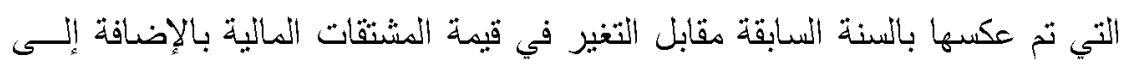

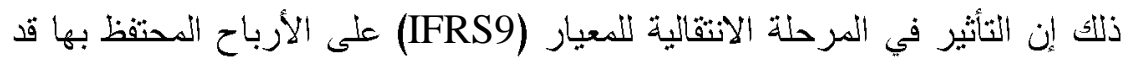

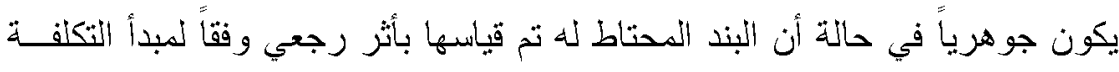

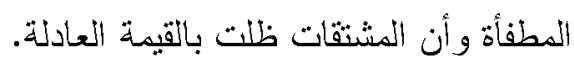

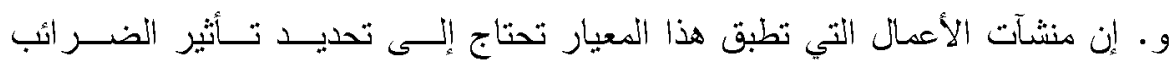

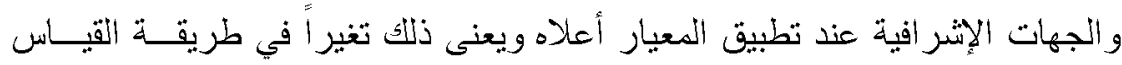
والأثر المثرتب على صافي الأرباح والخسائر للفترة المشمولة.

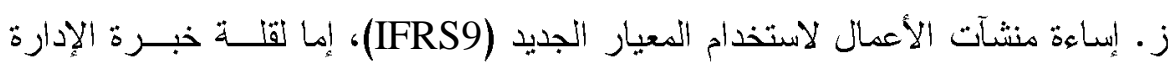

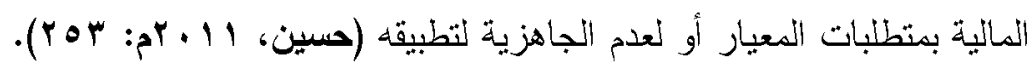


بناءة على ما سبق يشير (الباحث) أنه يجب على المصارف السودانية التى ترغب في لإني

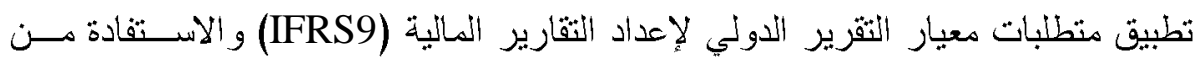

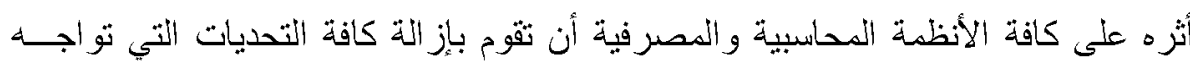

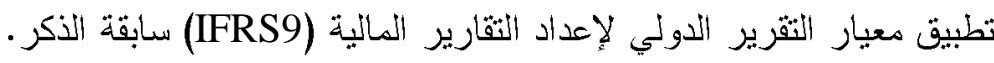

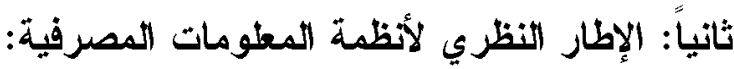

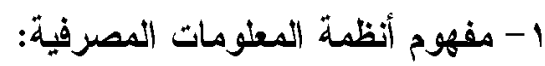

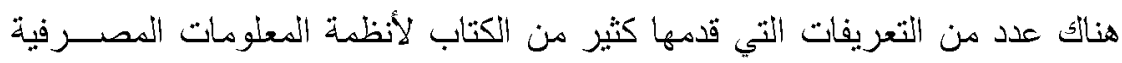

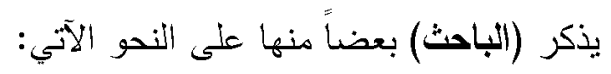

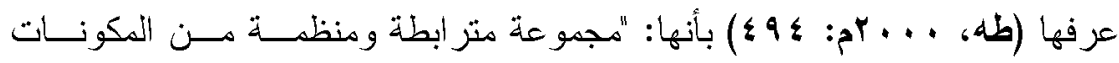

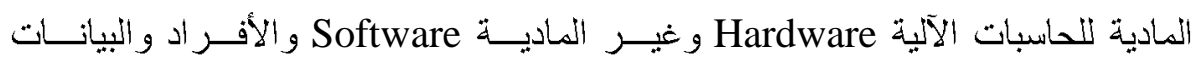

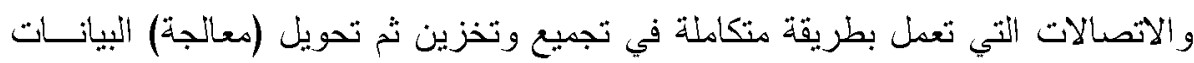

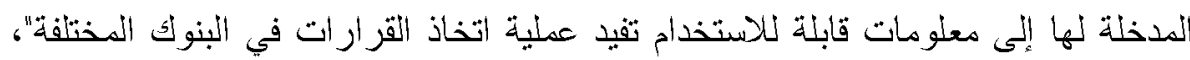

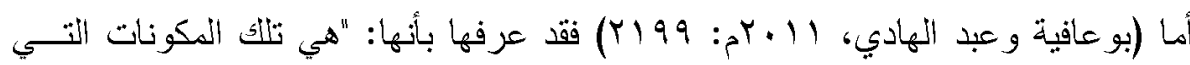

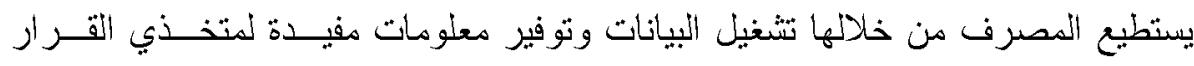

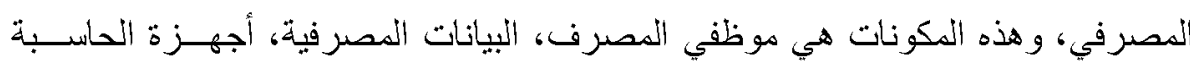

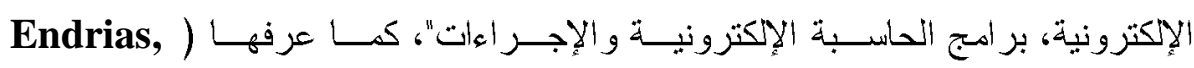

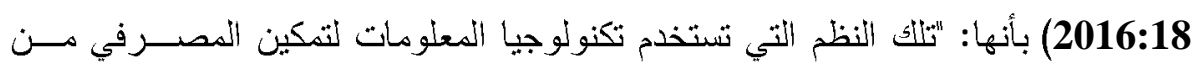

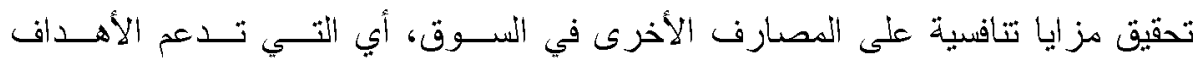
الإنستر تيجية".

من خلال التعريفات السابقة بعرف (الباحث) أنظمة المعلومات المصــرفية بأنهـا:

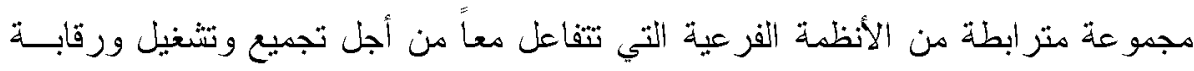

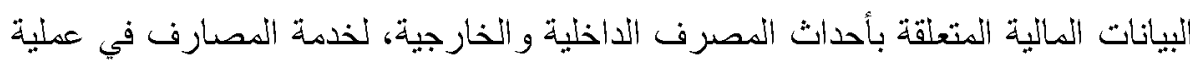
التخطيط، التتسيق، الرقابة، واتخاذ القر ارات الإدارية و الاستثنارية و الإستر اتيجية. r- أهية أنظة المعلومات المصرفية:

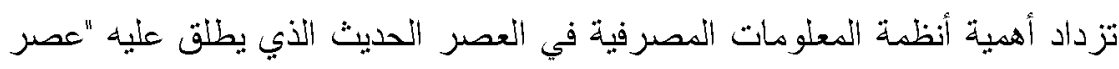

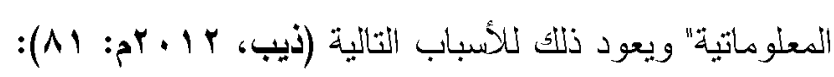
أ- إنثار المعلومات بثكل لم تثئهد البشرية سابقاً، وتعدد الوسائل المستخدمة.

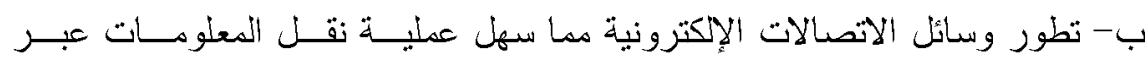

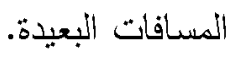


ج- تطور صناعة الحسابات الإكترونية التي ساعدت على تخزين كّـــ كبيــر مـنـ

$$
\text { المعلومات وسهلت الوصول إليها بسر عة. }
$$

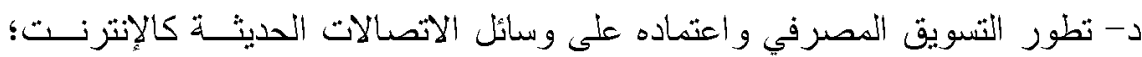

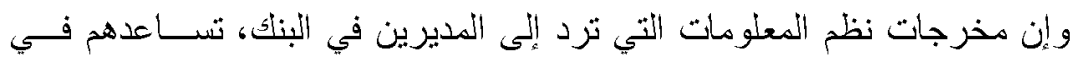

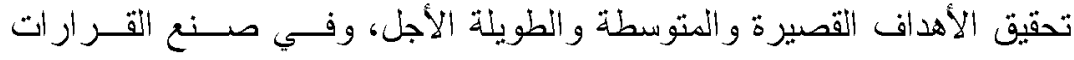

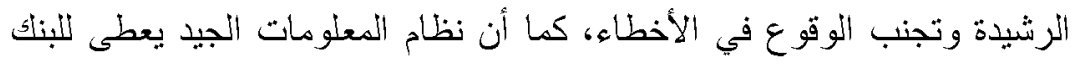

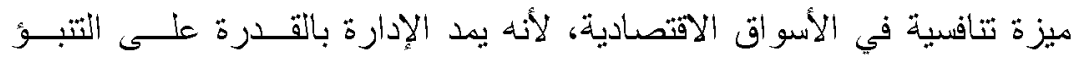

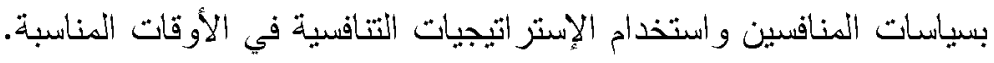

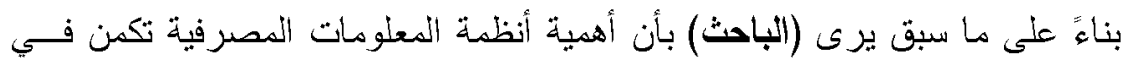

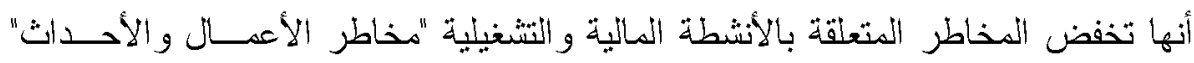

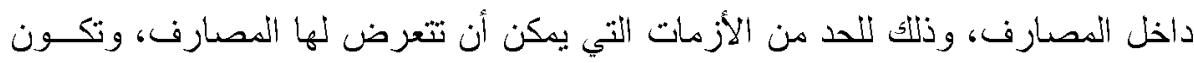

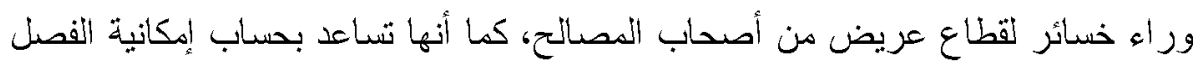

بين المهام عن طريق تتفيذ ورقابة آهنة "قو اعد بيانات نظم تشغيل". r- أهداف أنظمة المعلومات المصرفية:

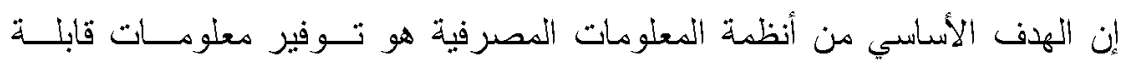

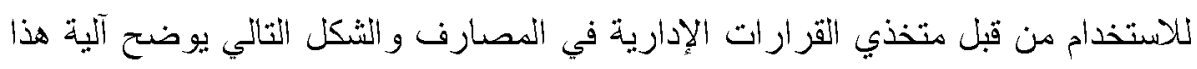

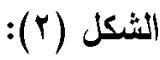

نظم المعلومات تساعد في اتخاذ القرارات الإدارية في المصارف

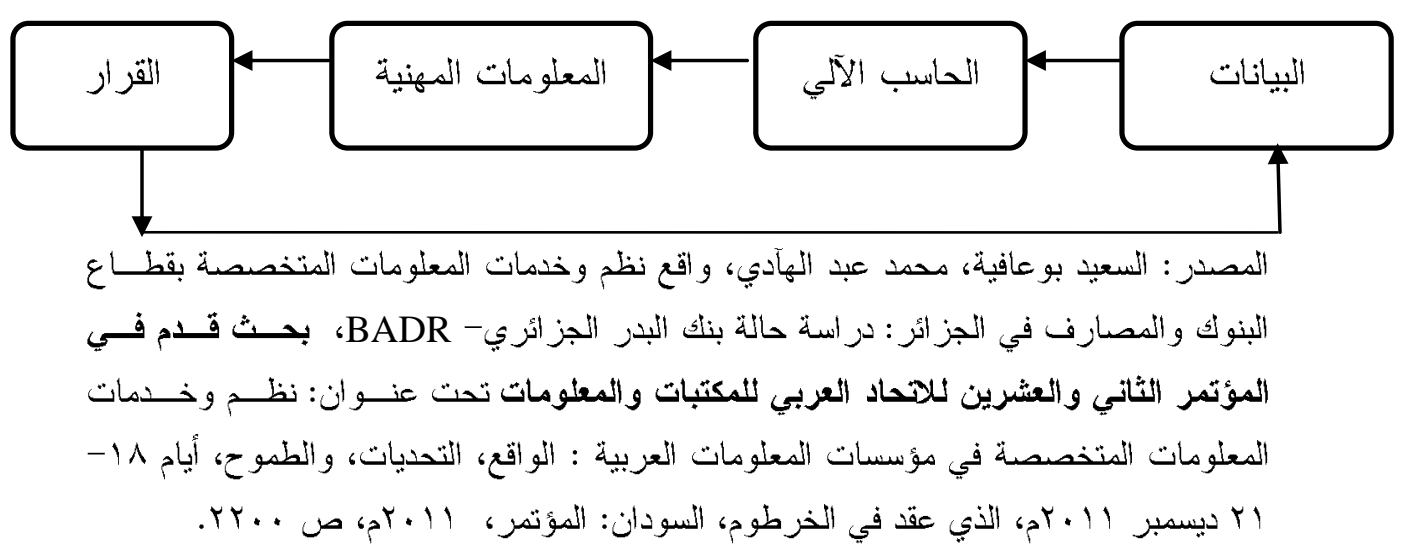


يلاحظ (الباحث) من خلال الثنكل (Y) أن أنظمة المعلومــات المصــرفية تتضــن

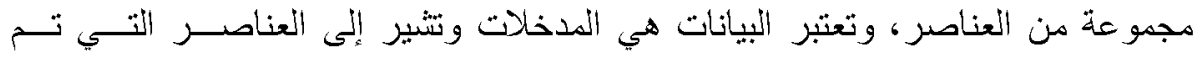

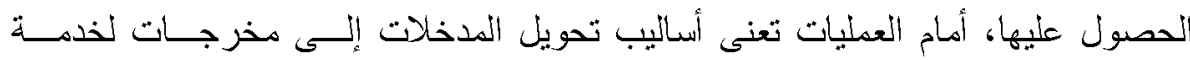
الغرض منها عبر حلقة المعلومات المهنية، ولذلك لتحقيق الفائدة المطلوبة منها في اتخـاذ

القرارات المختلفة.

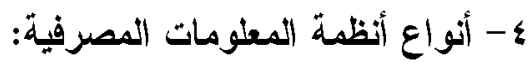

اختلف الباحثون في تقسييم أنظمة المعلومات المصرفية على أثنكال متعـددة يـذكر

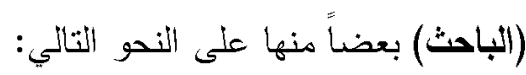

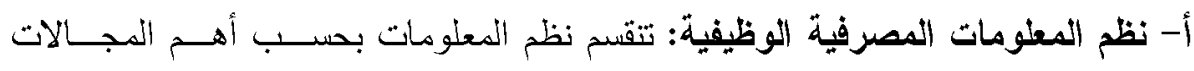

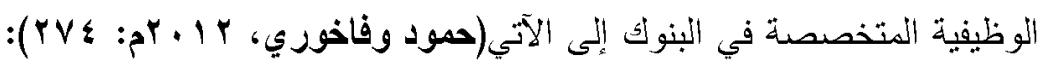

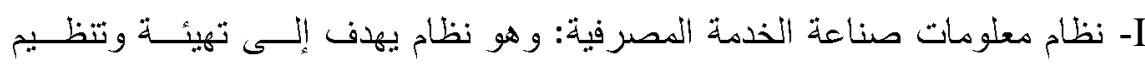

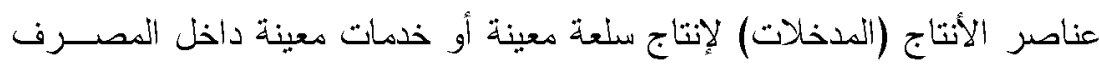

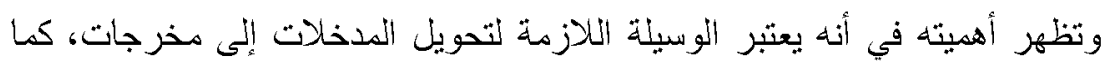

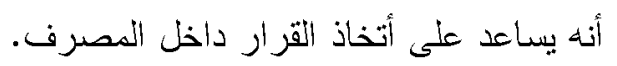

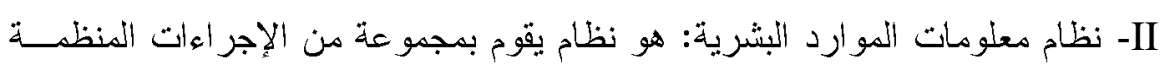

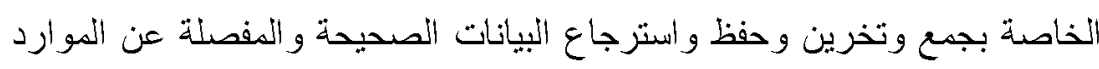

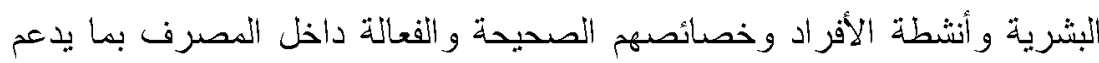

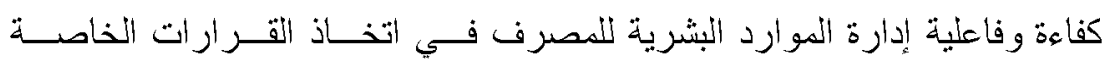

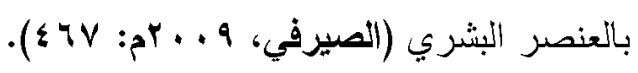

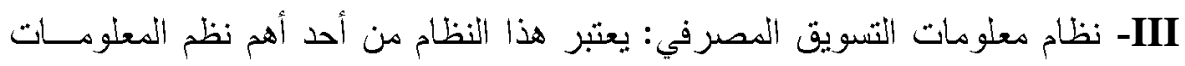

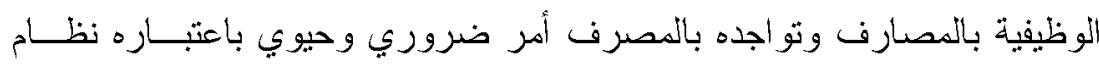

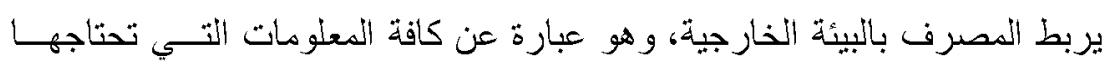

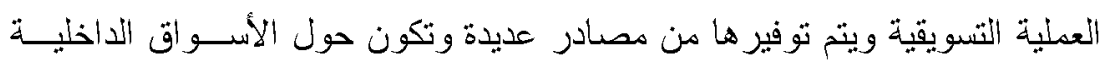

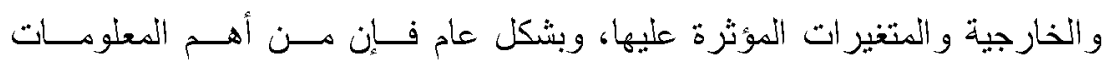

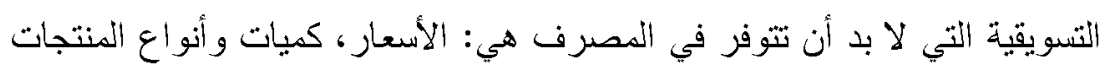

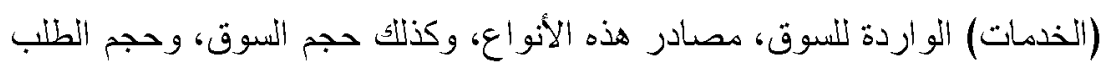

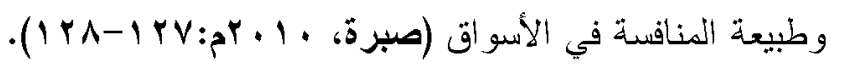




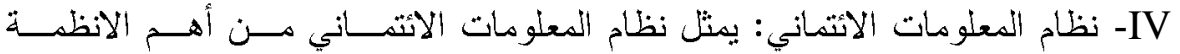

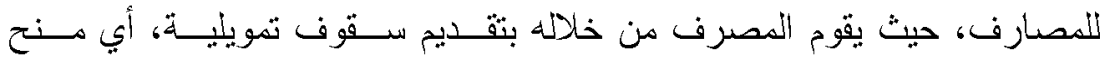

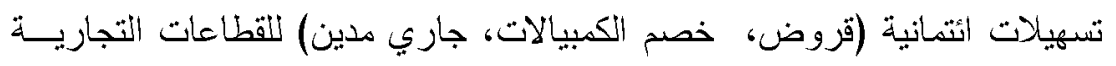

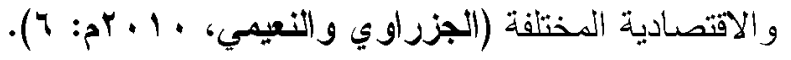

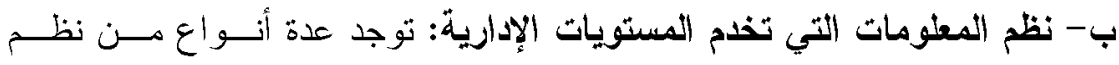

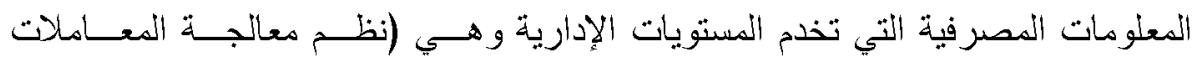

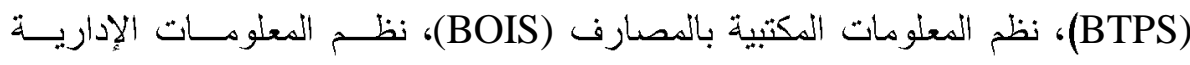
بالمصارف (BMIS)، نظم دعم القرار المصرفي (BDSS)، نظم دعــم الإدارة العليــا

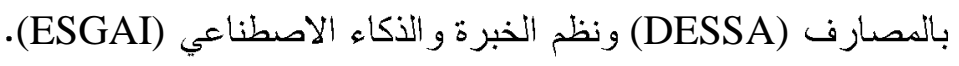
ه- تأثير المعيار الدولي للتقارير المالية (IFRS9) على أنظمة المصارف:

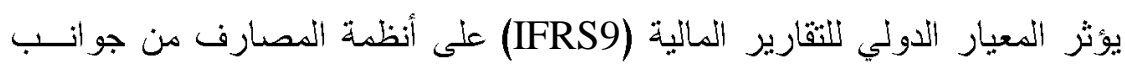

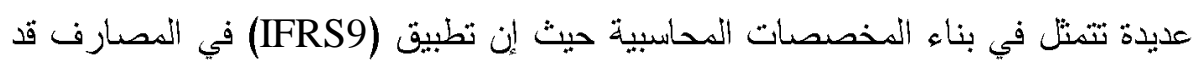

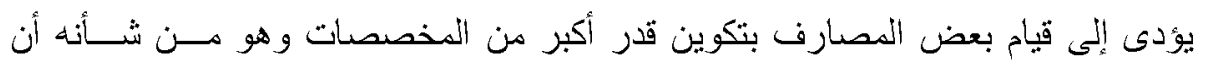

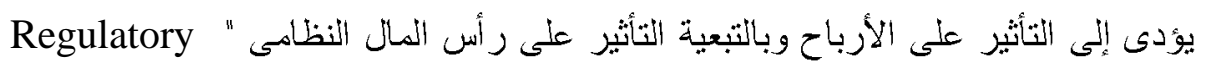

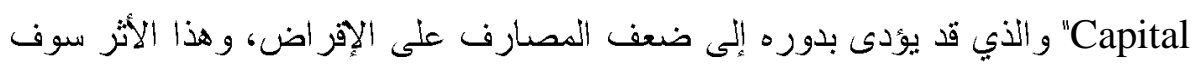

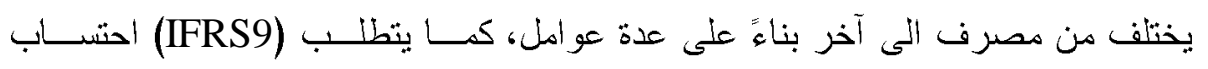

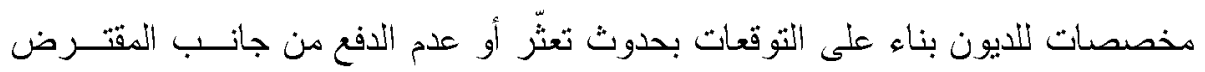

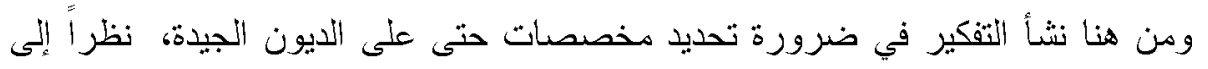

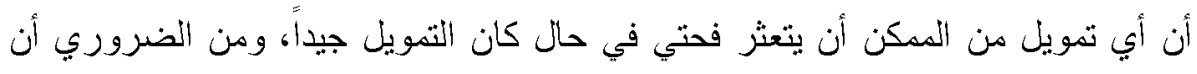
يحتسب أحتمال التخلف عن التسديد، و وأيضداً يوظف (IFRS9) حساب مخصص الخصن الخسائر كأساس تقييمى لقدرة المصرف على السداد في المستفبل، وتتكل هذه المعلومات تقييمساً

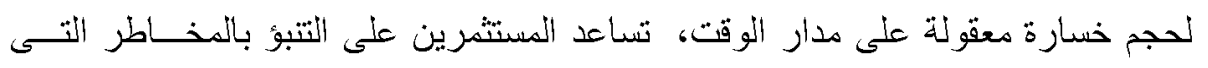

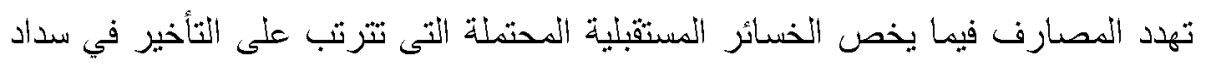

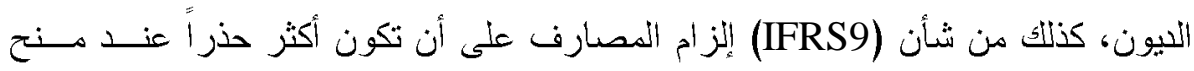

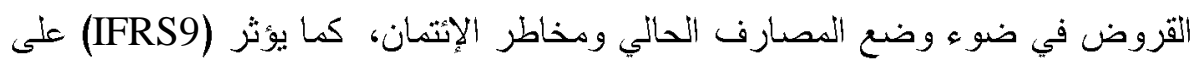

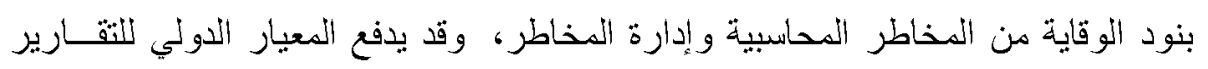
المالية (IFRS9) إلى أندماج المصارف متوسطة الحجم و الصغيرة في الوقت الذب وني يمكن

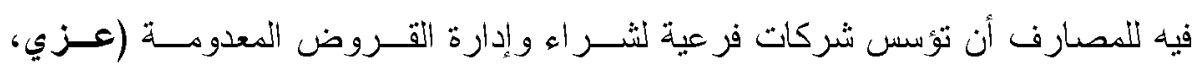

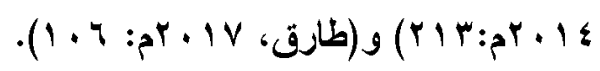




\section{المبحث الثاني: الدراسة المبدانية}

يشتمل هذا المبحث على اجر اءات الدر اسة المبدانية و التى تتمثل في وصف لمجتمع

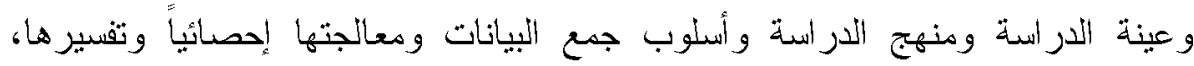
و إجر اء اختبار ات الثبات و الصدق للتأكد من صلاحيتها بالإضدافة إلى الأساليب الإحصائية التي تم بموجبها تحليل البيانات و استخر اج النتائج وذلك على النحو الثالي:

أولاً: مجتمع وعينة الدراسة:

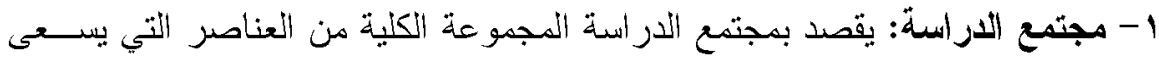

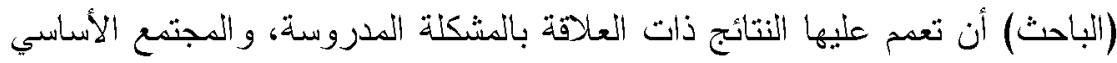

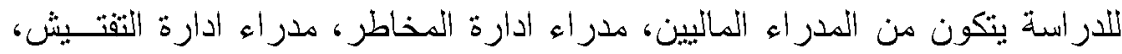

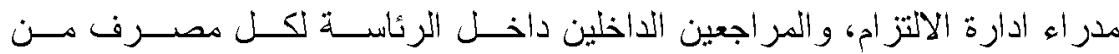

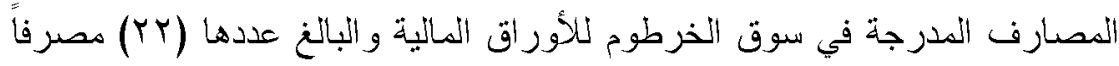
حسب الثقرير الأخير لسوق الخرطوم للأوراق المالية الثالث والعشرين.

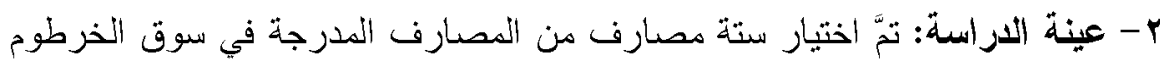

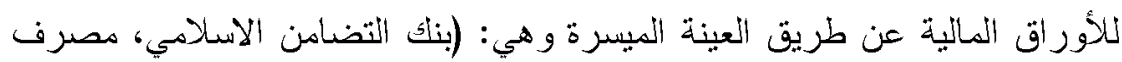

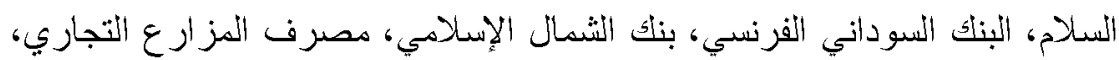

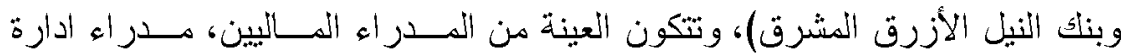

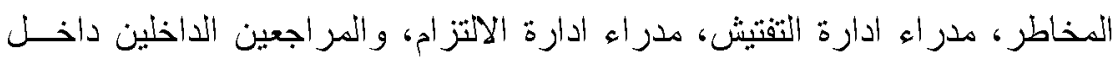

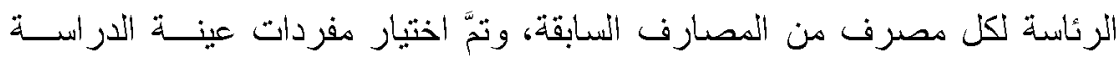

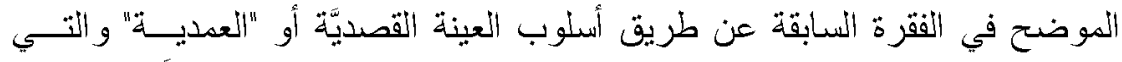

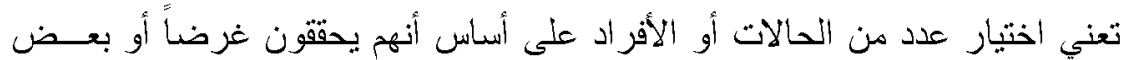

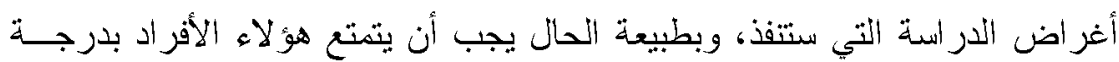

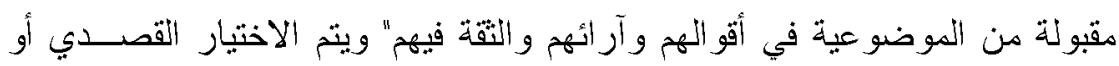

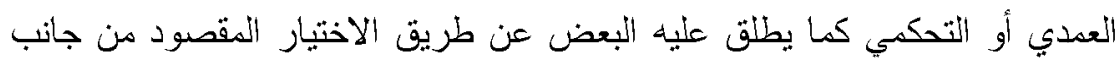

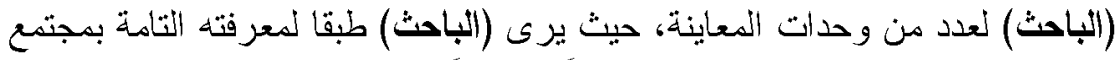

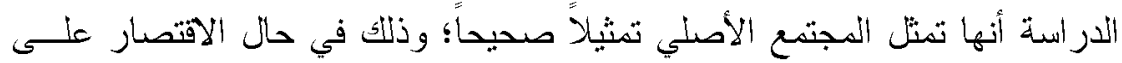

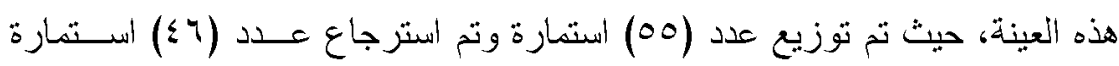

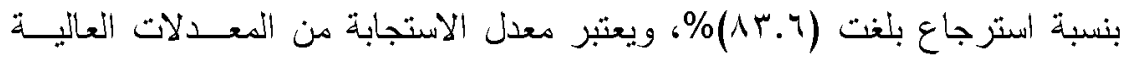

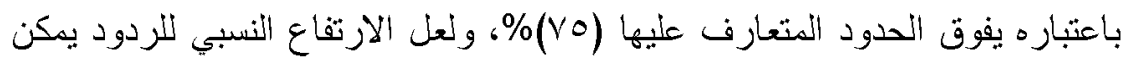

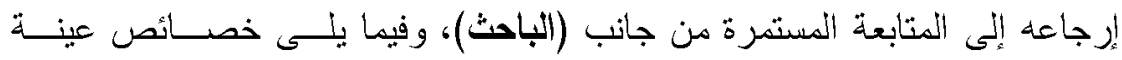


الجدول (ץ):

خصائص أفراد عينة الدراسة

\begin{tabular}{|c|c|c|c|}
\hline النسبة المئوية\%\% & التكرار & الفئات & المتغيرات \\
\hline$\% \leq . r$ & r & أقل من ·r سنة & \multirow{4}{*}{ 1/ العدر } \\
\hline$\% 10 . r \%$ & $\bar{v}$ & r r و أقل من ro سنة & \\
\hline \%Ү人.r & ir & مr و أقل من •ـ سنة & \\
\hline \%०r.r & $Y \leq$ & أ. سنة فأكثر & \\
\hline$\% \circ \wedge . \vee$ & TV & بكانوريوس & \multirow{4}{*}{ r/ المؤهل العلمي } \\
\hline$\% \wedge . \vee$ & $\leq$ & دبلوم عالي & \\
\hline$\%$ \%^.г & ir & ماجستير & \\
\hline$\% \leq . \leq$ & $r$ & دكتور اه & \\
\hline$\% 0$. & rt & محاسبة & \multirow{6}{*}{ r/ التخصص } \\
\hline \%rr.q & 11 & ادارة أعمال & \\
\hline$\% \wedge . \vee$ & $\leq$ & |قتصاد & \\
\hline$\% 1 r$ & 7 & علوم مالية ومصرفية & \\
\hline$\%$ \%.r & 1 & نظم معلومات & \\
\hline$\%$ \%.r & 1 & أحصاء & \\
\hline$\% \leqslant . \leqslant$ & 2 & زمالة القانونيين السودانية & \multirow{5}{*}{ ـ ـ المؤهل المهني } \\
\hline \%Y.Y & 1 & زمالة القانونيين العربية & \\
\hline$\%$. & . & زمالة القانونيين البريطانية & \\
\hline$\%$ & 0 & زمالة القانونيين الأمريكية & \\
\hline$\%$ \%r.z & $\leq r$ & لا لا توجد & \\
\hline \%०r.r & $r \leq$ & مر اجع داخلي & \multirow{3}{*}{ الأوظسيفي المسي } \\
\hline$\% 1 \cdot .0$ & 0 & مدير أدارة هخاطر & \\
\hline$\% 1 \cdot .0$ & 0 & مدير أدارة الالتز ام & \\
\hline$\% 1 r$ & 7 & مدير أُدارة التقتيث & \multirow{7}{*}{ 1/ سنو ات الخبرة } \\
\hline$\% 1 r$ & 7 & مدير مالي & \\
\hline$\% \leq . \leq$ & $\bar{r}$ & أقل من • سنو ات & \\
\hline$\% \backslash v . \Sigma$ & $\wedge$ & مو أقل من · أسنة & \\
\hline \%rr. 9 & 11 & • ا و أقل من 10 سنة & \\
\hline$\%$ \%.r & 1 & 0 ا و أقل من •r سنة & \\
\hline \%०r.r & $r \leq$ & 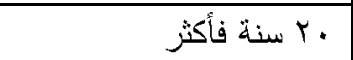 & \\
\hline
\end{tabular}

المصدر : إعداد (الباحث) من بيانات الاسنيان 9 1 + بم. 
تتمثل أداة جمع البيانات التي اعتمد عليها (الباحث) في الحصول علـى البيانـات

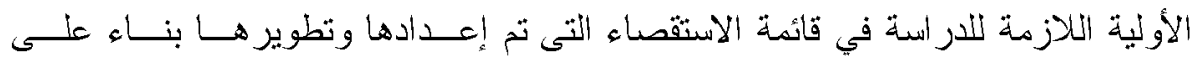
الاستعانة بالمقاييس التي وضعها (الباحث) للتعرف على الآثار المحتملة من تطبيق معيار

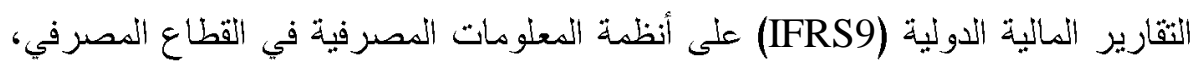
وتتكون الاستمارة من قسمين: 1- القسم الأول: يثتصل على البيانات الخاصدة بأفر اد عينة الدر استة.

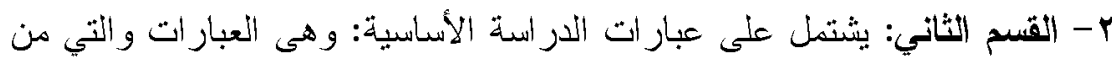

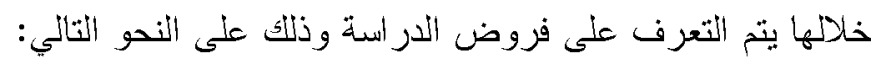

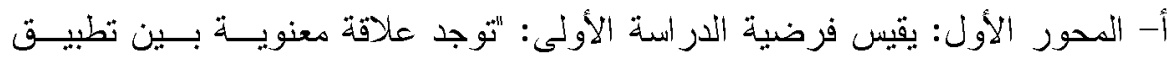

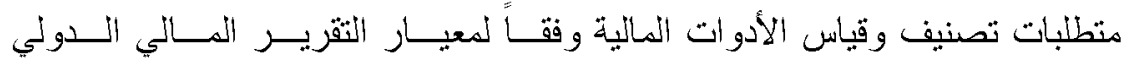
و وأنظمة المعلومات المصرفية في القطاع المصرفي السوداني".

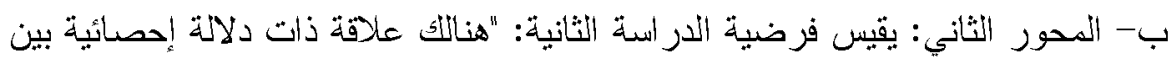
الاعتراف وقباس الخسائر الاتثمانية وفقاً لمعبار التقرير المالي الــدولي (IFRS9) و أنظمة المعلومات المصر فئة في القطاع المصرفي السوداني". ج- المحور الثالث: يقيس فرضية الدراسة الثالثة: "توجد علاقة ارتباط بــين الأثتــان

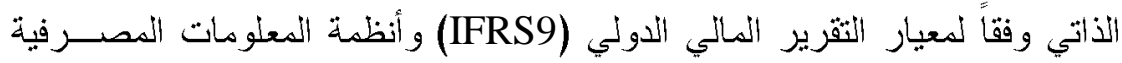
في القطاع المصرفي السوداني". د- المحور الر ابع: يقيس فرضية الدراسة الر ابعة: "توجد علاقة تأثير ذات دلالة معنوية

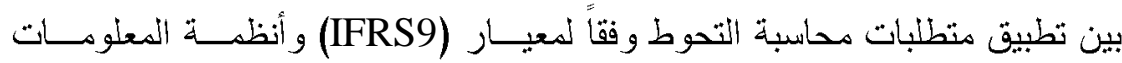

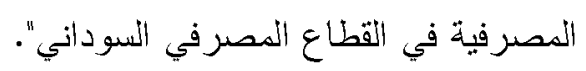

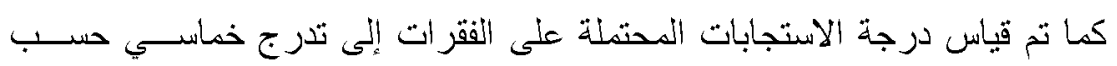
مقياس ليكرت الخماسي (Likart Scale).

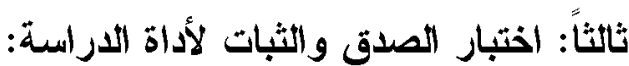

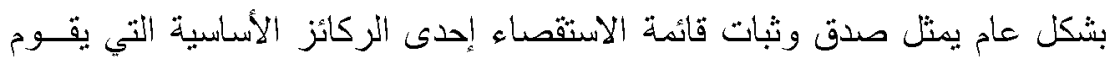

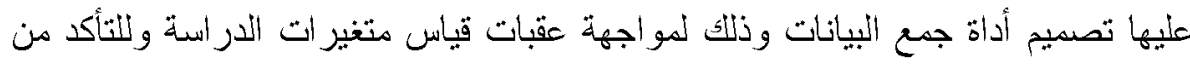

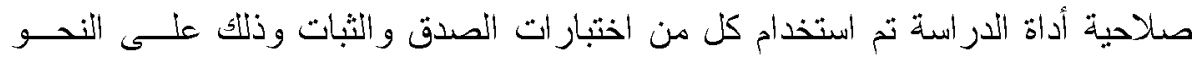


1- صدق أداة الاز اسة: يقصد بصدق أو صلاحية أُداة القياس قدرة الأداة على قياس مـــا صدمت من أجله وبناء على نظرية القياس الصحيح تعنى الصلاحية التامة خلو الأداة

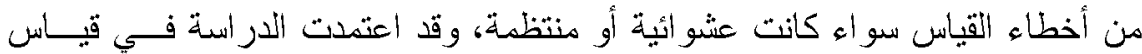
صدق أداة الدر اسة على كل من الآتي:

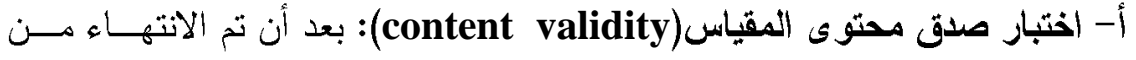
إعداد الصيخة الأولية لمقاييس الدراست وحتى يتم التحقق من صدق محتـوى أداة

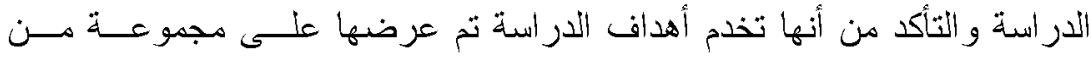
المحكمين والخبر اء المختصين بلغ عددهم (r) من المحكمين في مجال المحاسبة، المباء

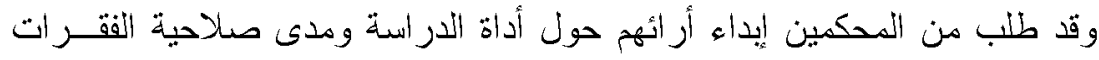

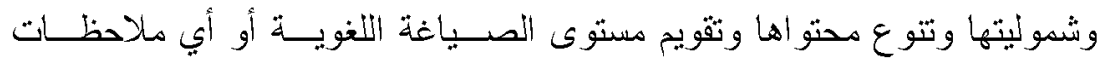

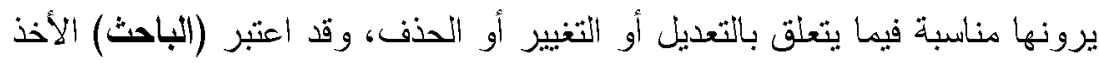

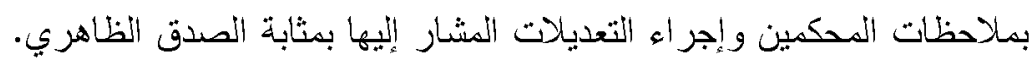
r- اختبار الثبات: من الصفات الأساسية التي ينبغي تو افرها أيضاً في أداة جمع البيانات

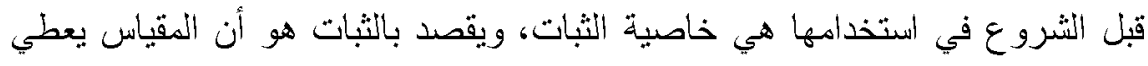

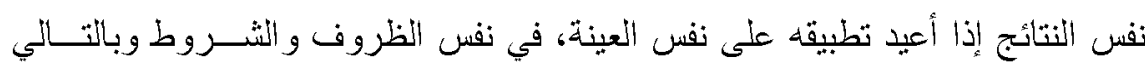

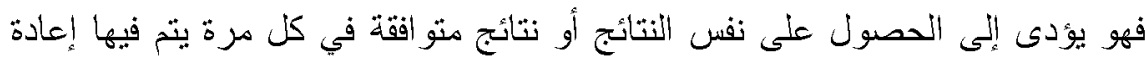
القياس، و اعتددت الار اسة على طريقة الفأ كرنباخ للتأكد من الاتساق الداخلي للمقاييس هو موضح على النحو التالي: ( الجدول (r): (ب)

نتائج اختبار الفأ كرنباخ لمتغير ات الأراسة

\begin{tabular}{|c|c|c|}
\hline معامل الفأ كرنباخ & عدد الفقرات & المحاور \\
\hline$. \lambda \leqslant$ & o & الفرضية الأولى \\
\hline. .11 & o & الفرضية الثانية \\
\hline .110 & 0 & الفزضية الثالثة \\
\hline. .19 & 0 & لقرضية الر ابعة \\
\hline
\end{tabular}

المصدر: إعداد (الباحث) من بيانات الاستيان 9 1. بم.

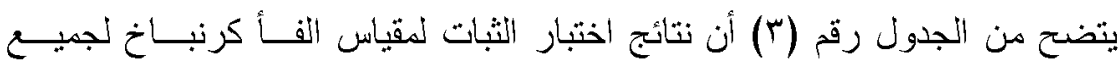

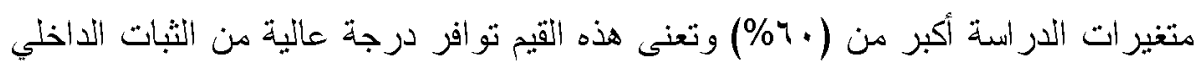
مما يمكننا من الاعتماد على هذه الإجابات في تحقيق أهداف الدراسة وتحليل نونيل نتائجها. 
رابعاً: أسائيب التحليل الإحصائي المستخدم في الدراسة:

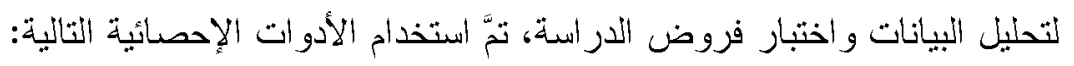

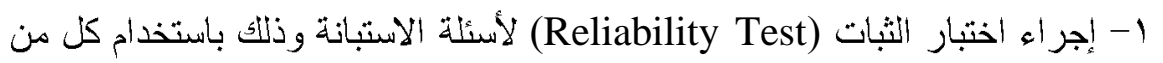

$$
\text { الآتي: }
$$

أ- اختبار الصدق الظاهري، ب- اختبار ات الصدق و الثبات.

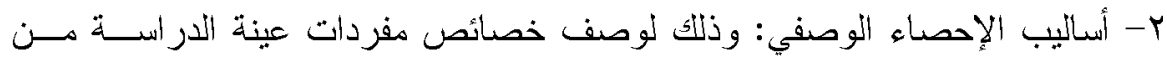

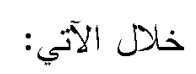

أ- الوسط الحسابي، ب- الانحر اف المعياري، ج- اختبار (T) لدلالة الفروق

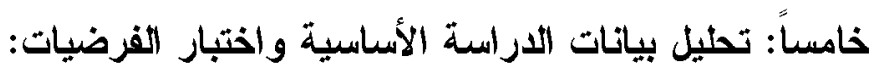

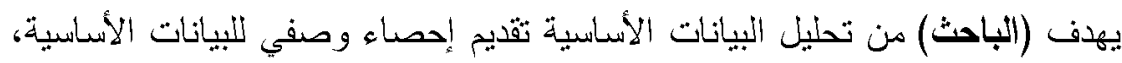

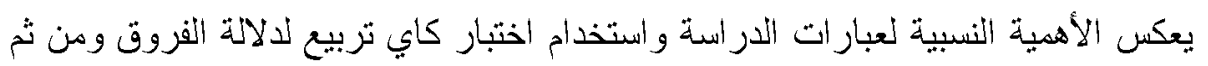

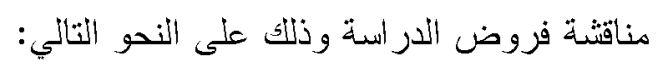

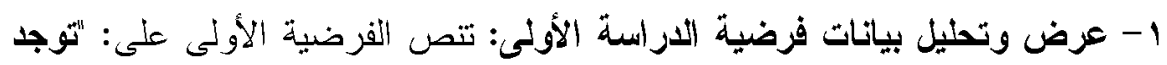

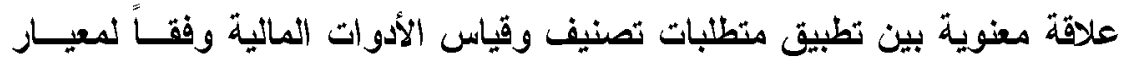

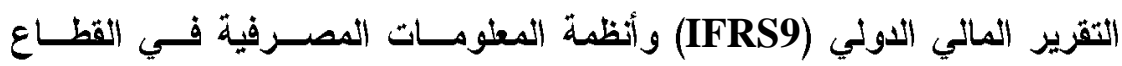

المصرفي السوداني"، وللتحقق عن مدى صحة الفرضية تم إتباع الخطو ات التالية:

\begin{tabular}{|c|c|c|c|c|c|c|c|c|}
\hline الثرتيب & مستؤ & فيمة t & الاستجابة & النسبي\% & المعباري & الحسابي & المتغبرات & p \\
\hline$r$ & $\ldots \ldots$ & $1 \% .1 \%$ & مرزتُعَ & $\% \wedge r$ &. .090 & $\$ .10$ & 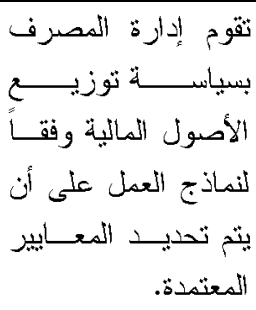 & 1 \\
\hline 1 & $\ldots r$ & 15.90 & مرزنعة & \%^r.q & $.0 \leqslant Y$ & 8.19 & 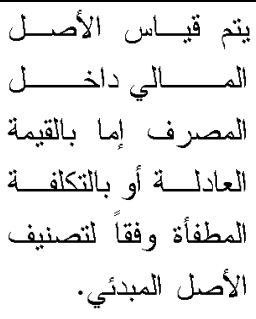 & $r$ \\
\hline
\end{tabular}

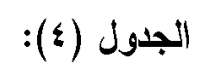

ملفص نتنائج التحليل الإحصائي لفرضية الدراسة الاوفي 


\begin{tabular}{|c|c|c|c|c|c|c|c|c|}
\hline الترنيب & مستوى الدالة & قيمة & الاستجابة & النسبي\% & الالميراف & المستوسب & المتنغيرات & e \\
\hline$r$ & $\ldots$ & $9 . V$ & مرنفاً & $\% \wedge .$. &. .799 & $\varepsilon$. & 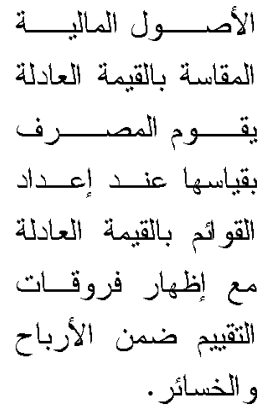 & $r$ \\
\hline 。 & $\cdots$ & $0 . r v$ & مرتفعة & $\% \mathrm{Vr}$ & . AYY & T.70 & 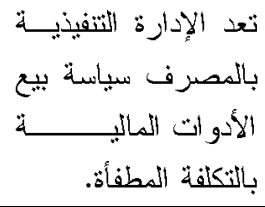 & $\varepsilon$ \\
\hline$\varepsilon$ & $\ldots \ldots$ & $7 . Y 4$ & مرتفعة & $\% \vee 4.9$ & .911 & r.A\& & 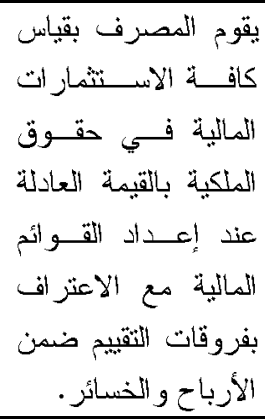 & 0 \\
\hline & 0.000 & 9.19 & مرتفعة & $79.4 \%$ & 0.715 & $r .9 V$ & اجمالي الثعبارات & \\
\hline
\end{tabular}

المصدر: إعداد (الباحث) من بيانات الاستيان 9 1 +rم.

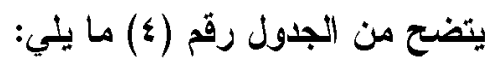

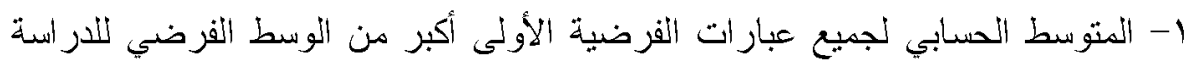

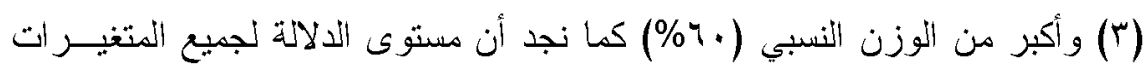

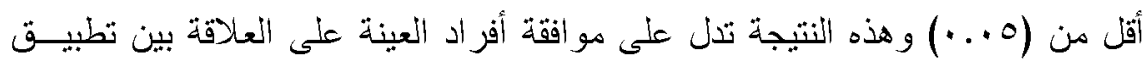
متطلبات تصنيف وقياس الأدوات المالية وفقاً لمعيار التثرير المالي الـدولي (IFRS9)

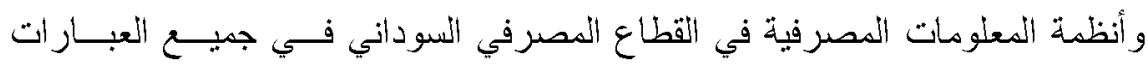
بدرجة استجابة مرتفعة حيث حققت جميع العبار ات متوسطاً عامــاً مقـداره (ب.9v)

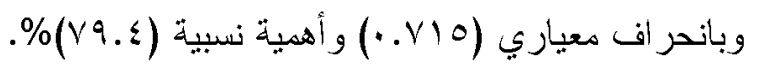


ب- يلاحظ من الجدول أن العبارة "يثت قياس الأصل المالي داخل المصرف إما بالقيــة

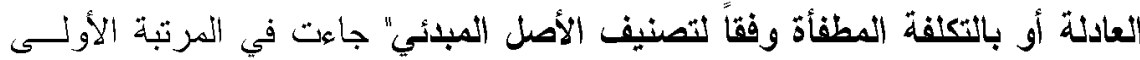

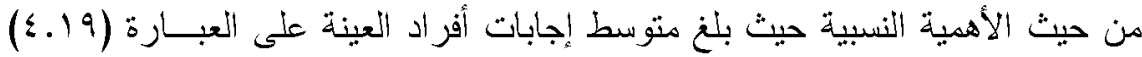

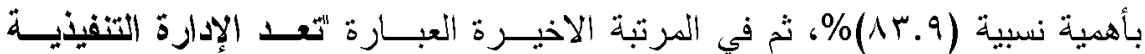

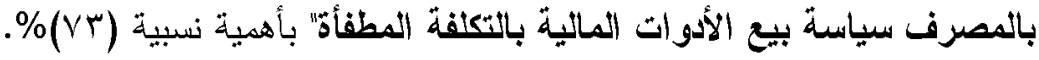

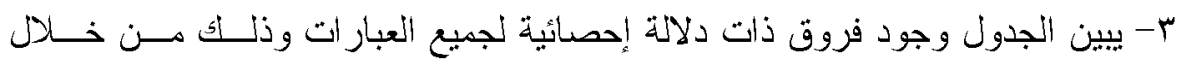

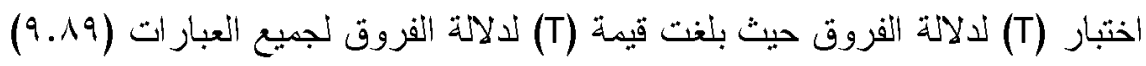

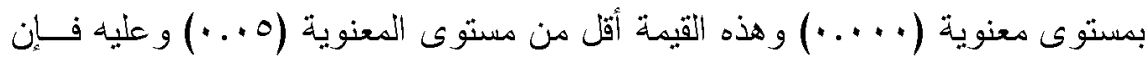

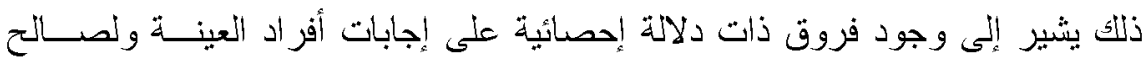

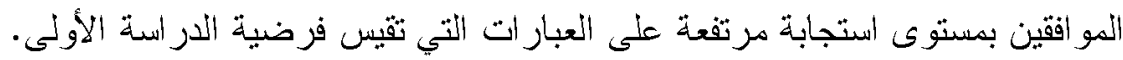

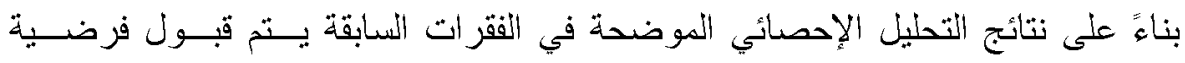

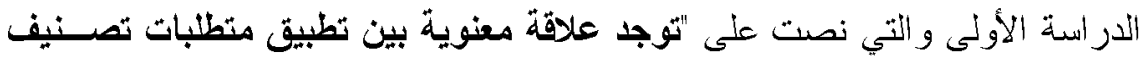

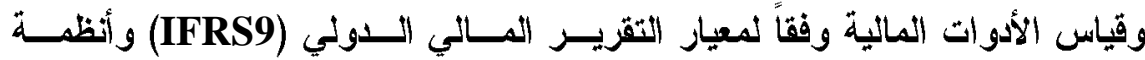
المعلومات المصرفية في الفطاع المصرفي السوداني" في جميع العبــار ات بمســتوى استجابة مرتفعة.

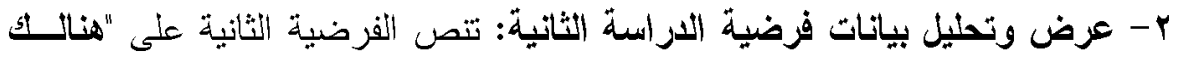

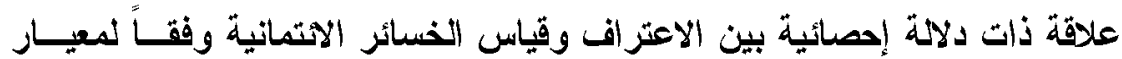

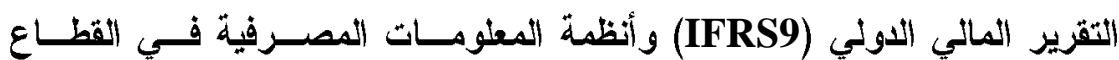

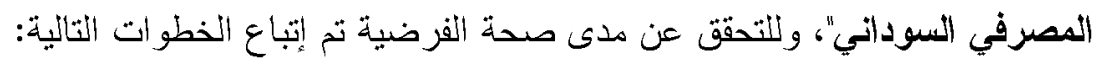

$$
\text { الجدول (0): }
$$

ملخص لنتائج التحليل الاحصائي لفرضية الاراسة الثانية

\begin{tabular}{|c|c|c|c|c|c|c|c|c|}
\hline الترتبب & مستوى الالالة & قيمة & الاستجابة درجة & الموزن النسبي\% & الانحراف & المتوسط الحسبي & المتغير ات & a \\
\hline$\varepsilon$ & $\ldots$ & A. 19 & هرتفعة & $\% \vee 9.1$ &. VYA & $r .90$ & 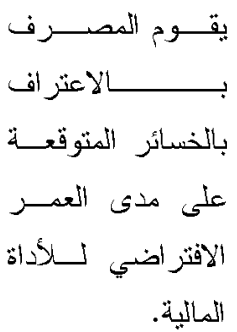 & 1 \\
\hline
\end{tabular}




\begin{tabular}{|c|c|c|c|c|c|c|c|c|}
\hline الثرتيب & مستوى اللالة & قيمة t & الاستجابة & النسبي\% & المعياري & المسنوسي & المتغيرات & p \\
\hline 。 & $\ldots$ & 0.1. & مرتفعة & $\% \vee r . \varepsilon$ &. .190 & r.TV & 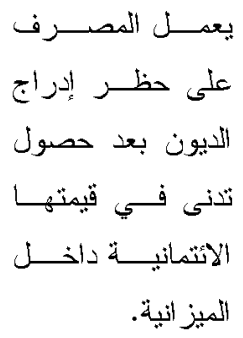 & $r$ \\
\hline$r$ & $\cdots$ & $1 T . r A$ & مرتفعةً & $\% \wedge \uparrow . \vee$ & .00 & $\{. .1$ & 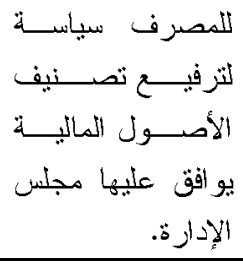 & $r$ \\
\hline 1 & $\cdots$ & $11 . \mathrm{V}$ & مرنفِة & $\% \wedge 1.9$ & $.7 K 4$ & $2 . .9$ & 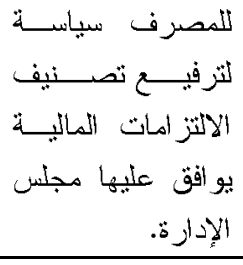 & $\varepsilon$ \\
\hline$r$ & $\ldots \ldots$ & 11.0 & مرتفعة & $\% \vee 9.0$ & .087 & r.9v & 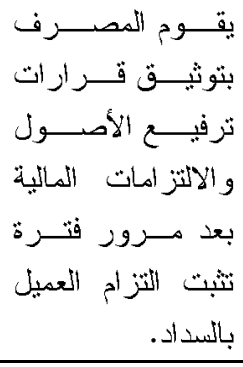 & 0 \\
\hline & 0.000 & $1 . .11$ & مرتفعة & $79.1 \%$ & 0.675 & 3.95 & اجمائي الثبارات & \\
\hline
\end{tabular}

المصدر : إعداد (الباحث) من بيانات الاستيان 9 1 +rم.

يتضح من الجدول رقم (ه) ما يلي:

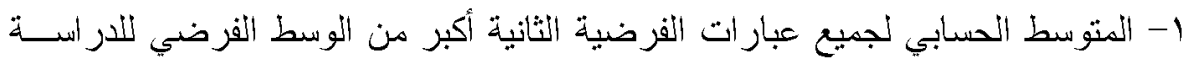

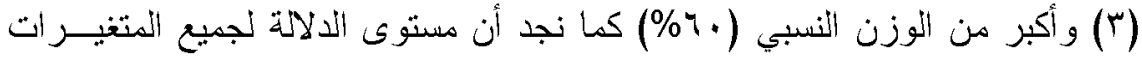

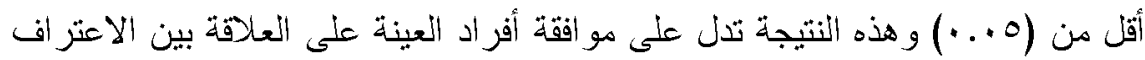

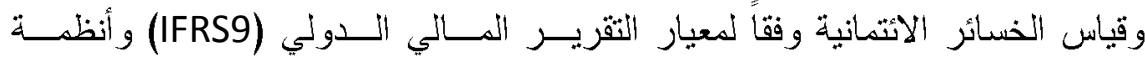

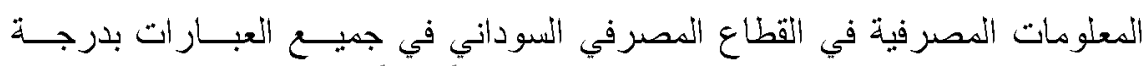

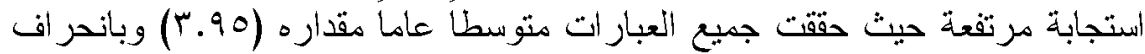

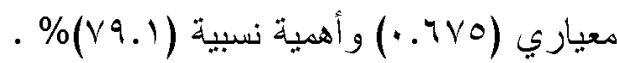


r- يلاحظ من الجدول أن العبارة " للمصرف سياسة لترفيع تصنيف الآتزامات المائيـة

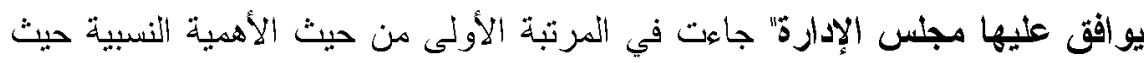

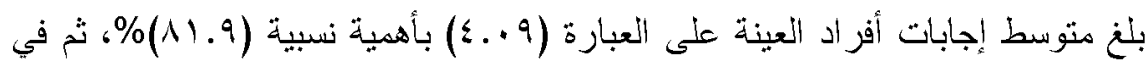

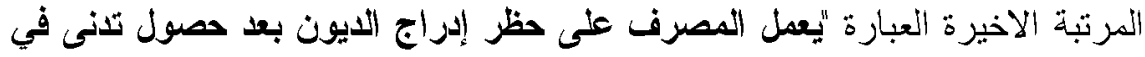

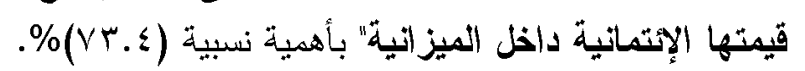

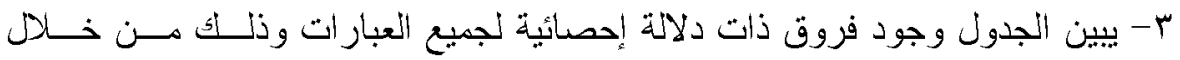

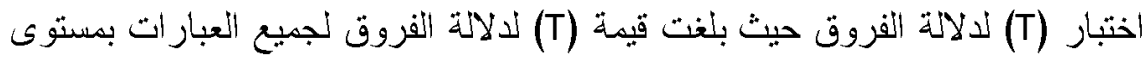

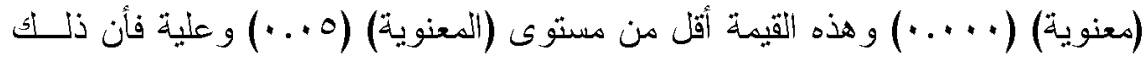

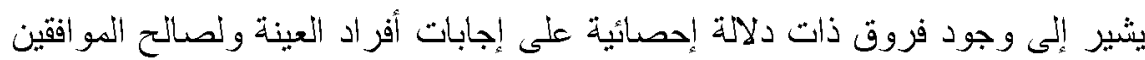

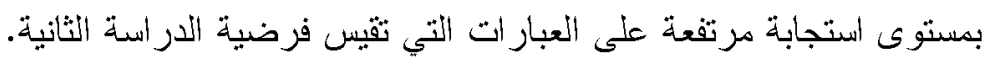

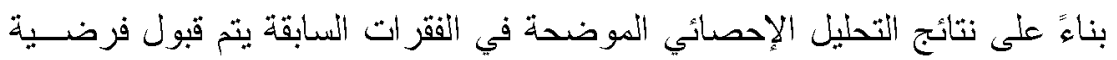

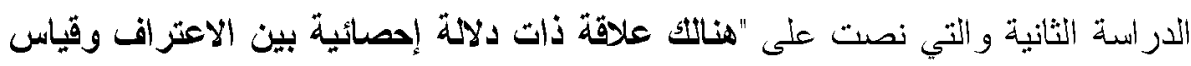

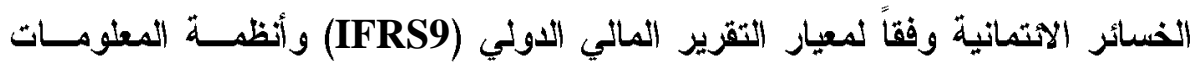
المصرفية في القطاع المصرفي السوداني" في جميع العبار ات بمستوى استجابة مرتفعة.

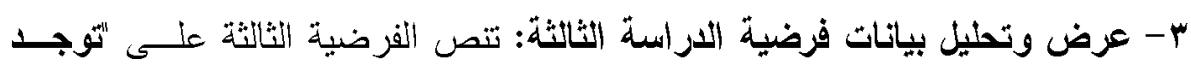

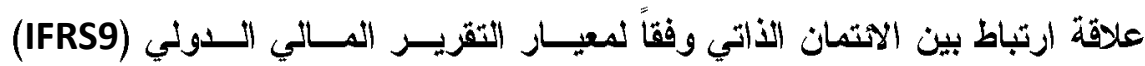

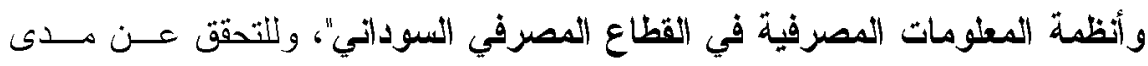
صحة الفرضية تم إتباع الخطو ات التالية:

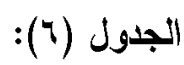

ملذص لنتائج التحليل الإحصائي لفرضية الدراسة الثالثة

\begin{tabular}{|c|c|c|c|c|c|c|c|c|}
\hline الثترتيب & اللالهتو & فيمة t & الاستجابة & النبنية\% & المعبرافي & الحسابي & المتنغيرات & P \\
\hline r & $\ldots \ldots$ & 1.71 & مرتاً & $\% \wedge \cdot . \wedge$ &. .110 & $\varepsilon . . \varepsilon$ & 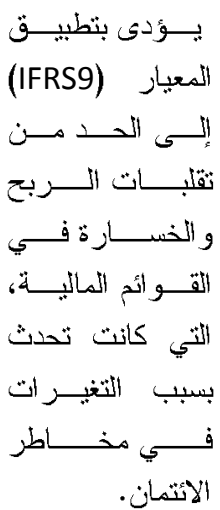 & \\
\hline
\end{tabular}




\begin{tabular}{|c|c|c|c|c|c|c|c|c|}
\hline الثرتيب & مستوى & t قيمة & الاستجابة درجة & النسبي\% الوزن & الانحر اف الميار ي & المستوسط المسبي & المتغيرات & b \\
\hline$\varepsilon$ & $\ldots r$ & $\mid . Y 1$ & هرتفعة & $\% \vee 9.0$ & .7199 & $r .9 \mathrm{~V}$ & 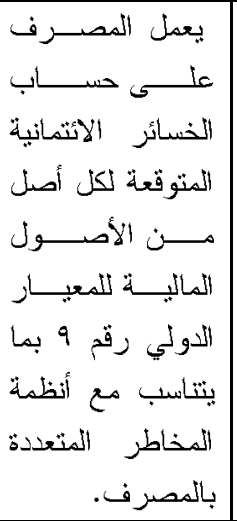 & $r$ \\
\hline 1 & $\cdots \cdots$ & IT.TV & مرتفِّة & $\% \wedge r .$. & $.9+1$ & 2.10 & 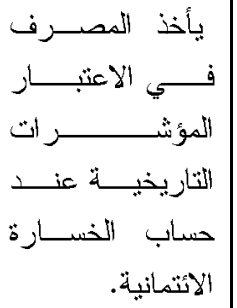 & $r$ \\
\hline r & $\cdots \cdots$ & 9.7. & مرتفةً & $\% \wedge \cdot . \wedge$ &.$V Y A$ & \&.. & 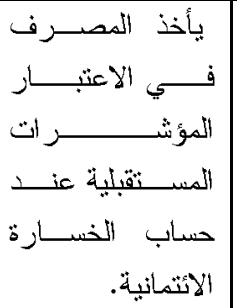 & $\varepsilon$ \\
\hline 0 & $\ldots+$ & $0 . \Delta r$ & مرتفعة & $\% \vee \leq . r$ & . .ArE & r.VI & 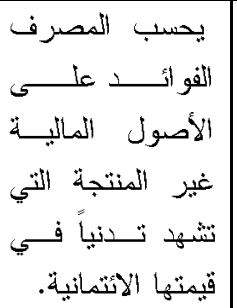 & 。 \\
\hline & 0.000 & 9.47 & مر تفعة & 79.85 & 0.731 & $r .99$ & إجمالي العبارات & \\
\hline
\end{tabular}

المصدر : إعداد (الباحث) من بيانات الاستبيان 19 +rم.

$$
\text { يتضح من الجدول رقم (؟) ما يلي: }
$$

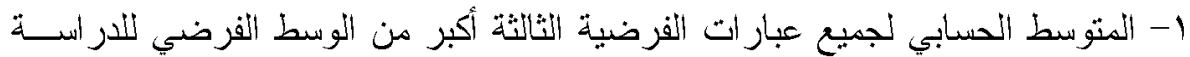

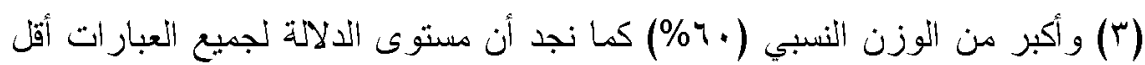
من (0...) وهذه النتيجة تدل على مو افقة أفر اد العينة على العلاقــة بــين الأتثــان 


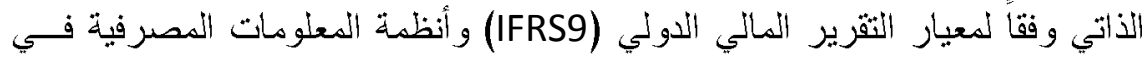

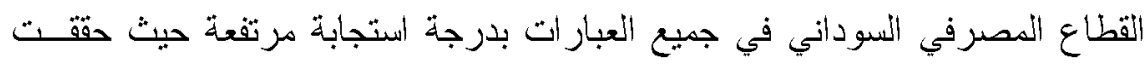

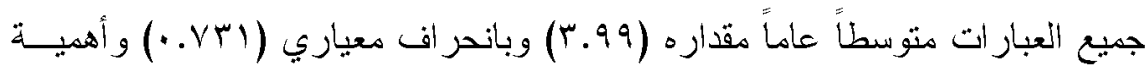

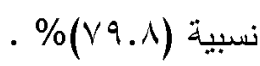

r- بلاحظ من الجدول أن العبارة "يأخذ المصرف في الاعتبار المؤشرات التاريخية عند

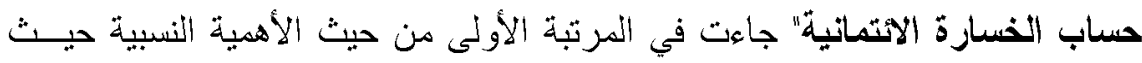

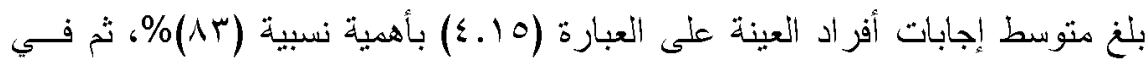

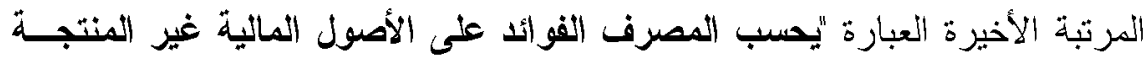

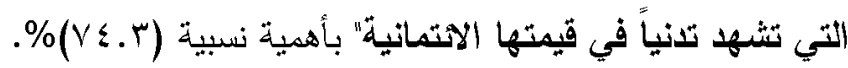

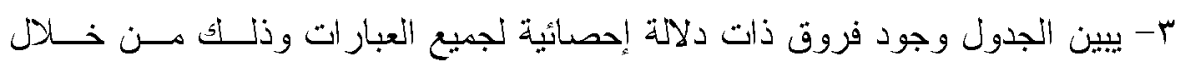

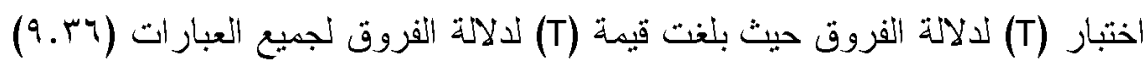

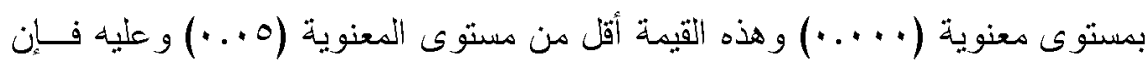

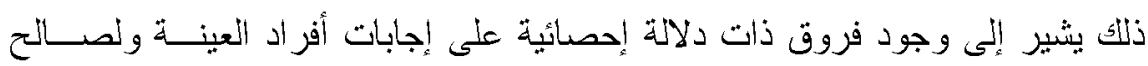

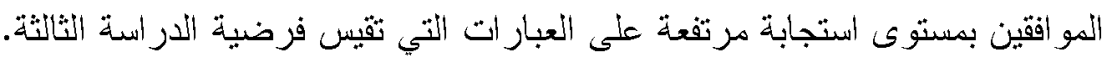

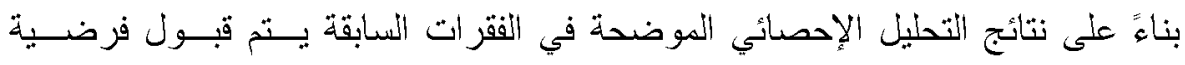
الأدر اسدة الثالثة و التي نصت على "توجد علاقة ارتباط بين الاتنمان الأني وفقاً لمعيار التقرير المالي الدولي (IFRS9) وأنظمة المعلومات المصرفية في القطاع المصرفي

$$
\text { السوداني" في جميع العبار ات بمستوى استجابة مرتفعة. }
$$

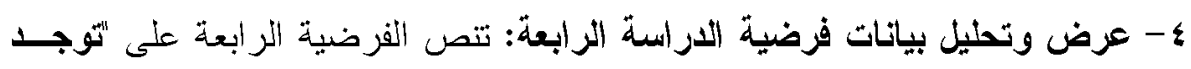

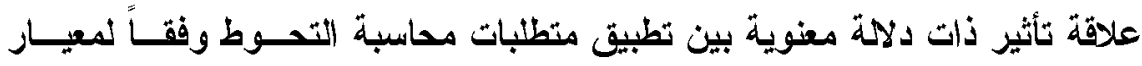

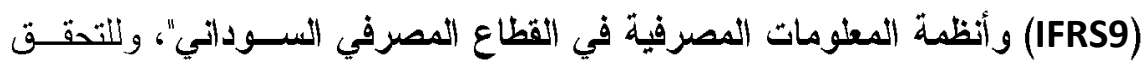
عن مدى صحة الفرضية تم إتباع الخطوات التالية:

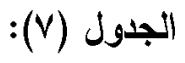

\begin{tabular}{|c|c|c|c|c|c|c|c|c|}
\hline الثرتبب & مستوى الدلاية & فيمة t & الاستجابة & 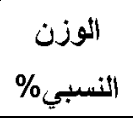 & |المعياري & المستوسط & المتغبرات & e \\
\hline$r$ & $\ldots$ & $11 . \wedge r$ & مرتفعة & $\% \wedge 1 . r$ &. .711 & $\varepsilon .+4$ & 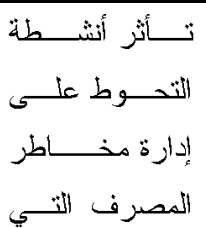 & 1 \\
\hline
\end{tabular}




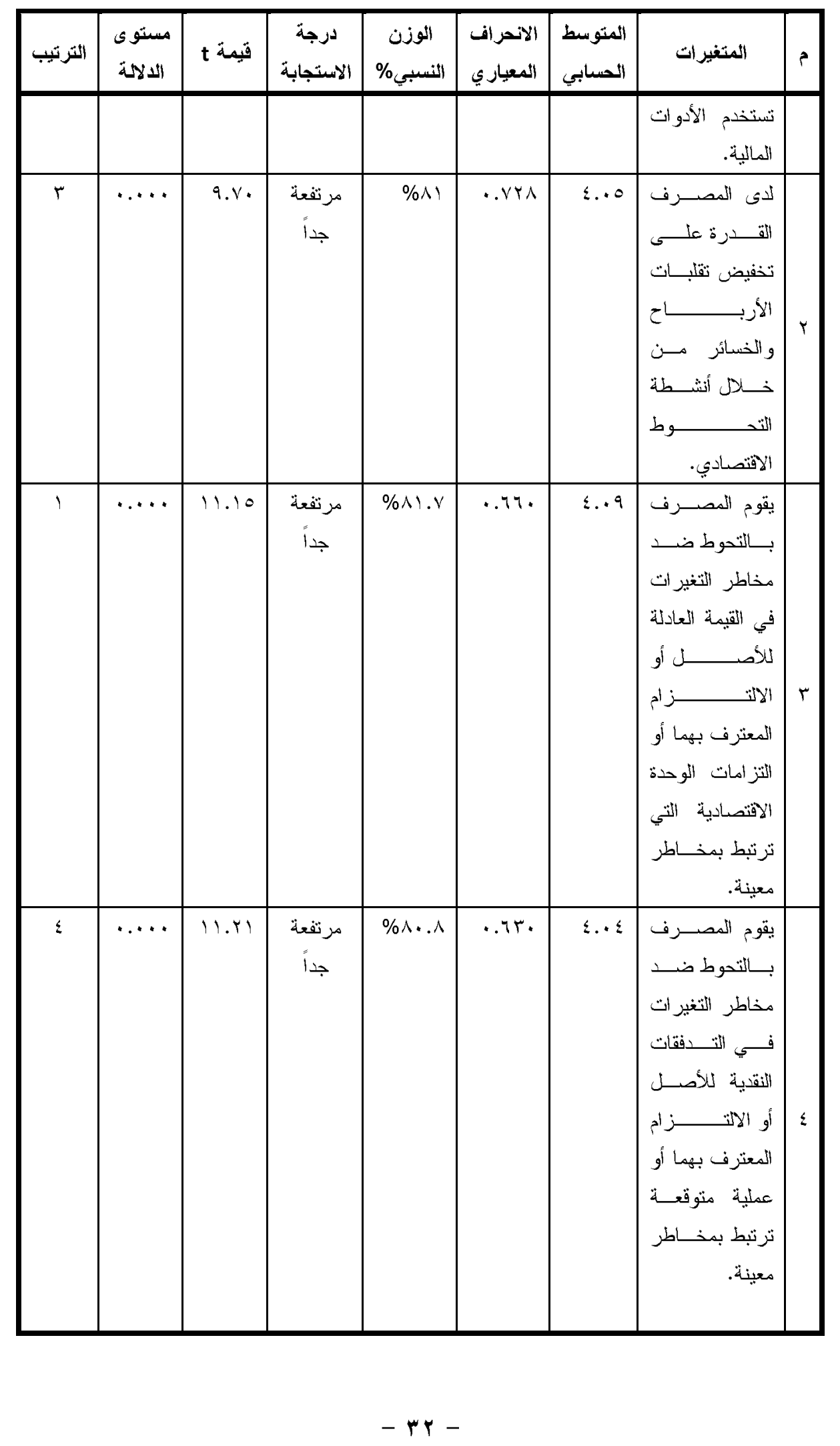




\begin{tabular}{|c|c|c|c|c|c|c|c|c|}
\hline الثرتيب & مستوى & قيمة t & الاستجابة & $\begin{array}{l}\text { اللوزبي\% } \\
\text { النسبن }\end{array}$ & الالمعيار ي & المسنوسي & المتّغيرات & e \\
\hline \multirow[t]{2}{*}{ 。 } & $\ldots$ & q. vo & مرتفعة & $\%$ หq. 1 &. .740 & $r .90$ & 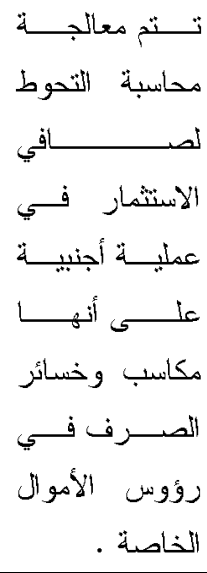 & 0 \\
\hline & $\ldots$ & $1 . . v r$ & هرتفعة & $\% \wedge \ldots \wedge$ &. $.7 \Delta q$ & $\{. . \leqslant$ & إجمالي العبارات & \\
\hline
\end{tabular}

المصدر: إعداد (الباحث) من بيانات الاستبيان 9 1ابكم.

يتضح من الجدول رقم (V) ما يلي:

1- المنوسط الحسابي لجميع عبار ات الفرضية الرابعة أكبر من الوسط الفرضي للإر أسة

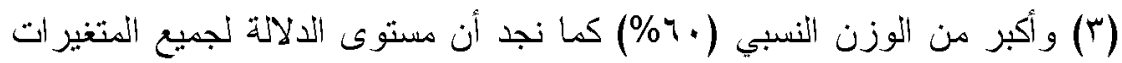
أقل من (0. . •) وهذه النتيجة تدل على موافقة أفراد العينة على العلاقة بين تطبيق

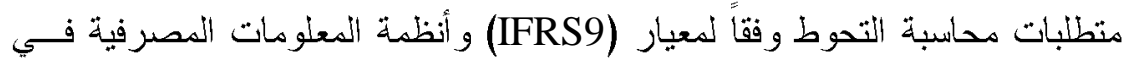

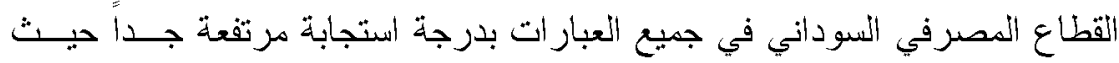

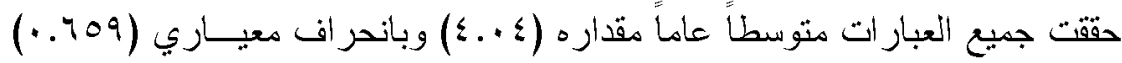

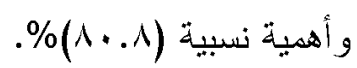

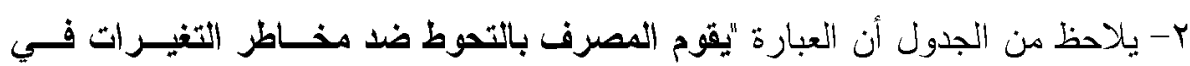

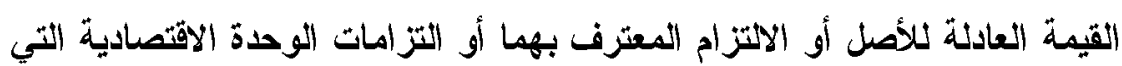

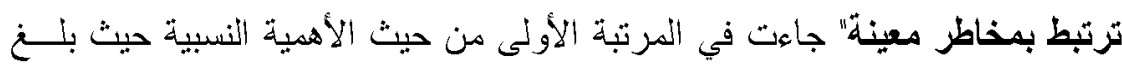

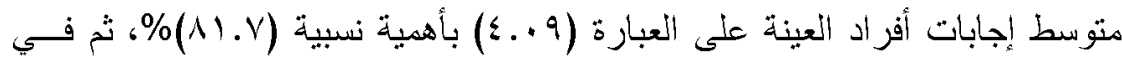
المرتبة الاخيرة العبارة "تثت معالجة محاسبة التحوط لصافي الاسنثمار في عمليـة فئة

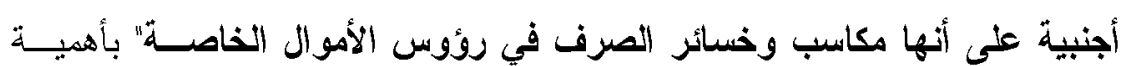




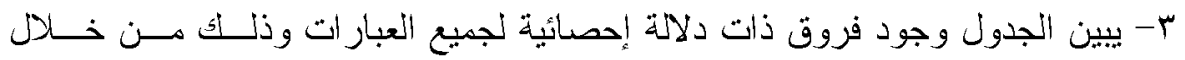

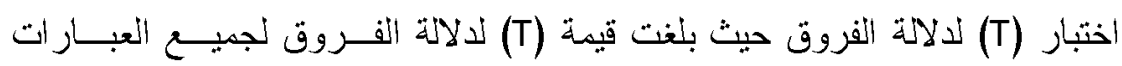

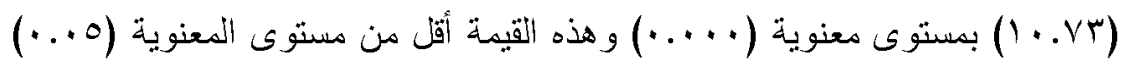

و عليه فإن ذلك يشير إلى وجود فروق ذات دلالة إحصائية على إجابات أفر اد العينة

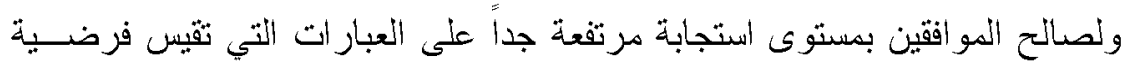

$$
\text { الدر استة الر ابعة. }
$$

بناءٌ على نتائج التحليل الإحصائي الموضحة في الفقر ات السابقة يتم قبول فرضــية

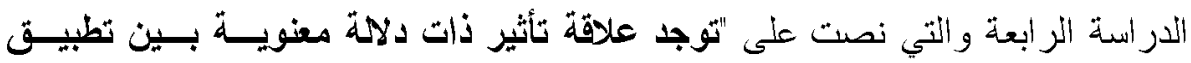

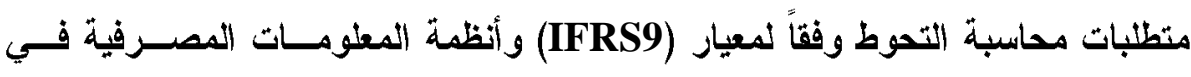
القطاع المصرفي السوداني" في جميع العبار ات بمستوى استجابة مرتفعة جداً.

\section{الخاتمة}

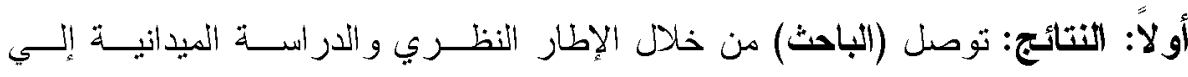

$$
\text { مجمو عةٍ من النتائج نتلخص في الآتي: }
$$

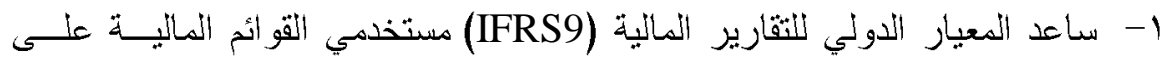

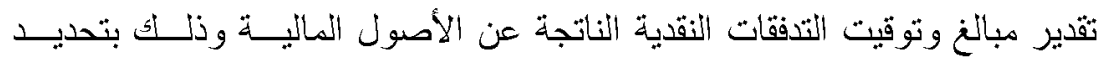

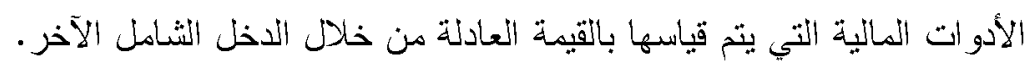

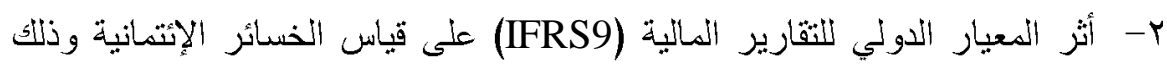

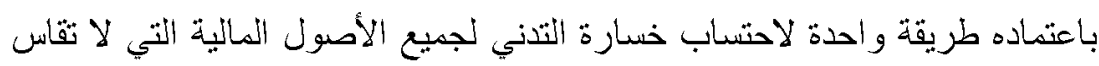

$$
\text { بالقيمة العادلة. }
$$

r- نتج عن تطبيق المعيار الدولي للتقارير المالية (IFRS9) العديد من المنافع منهـــا

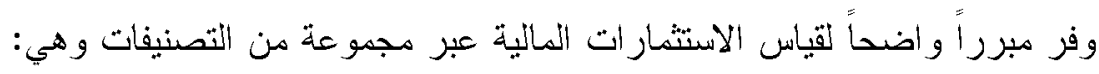

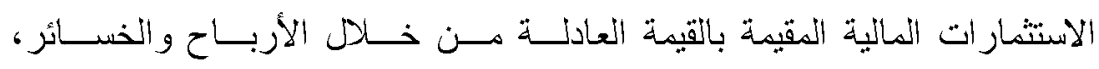

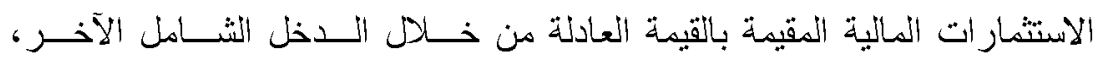

$$
\text { و الاستثمار ات المالية المقيمة بالتكلفة المستهدفة. }
$$

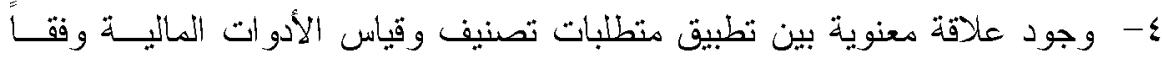
لمعيار التقرير المالي الذولي (IFRS9) و أنظمة المعلومات المصرفية فئهية في القطاع

$$
\text { المصرفي السوداني. و هذا يعزز نتيجة الفرضية الأولي. }
$$




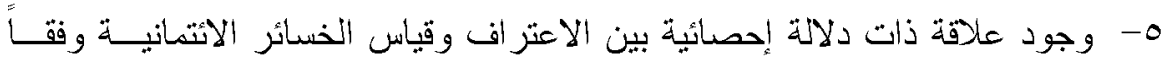

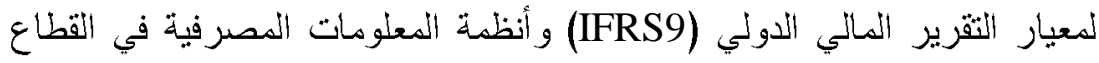
المصرفي السوداني. وهذا يعزز نتيجة الفرضية الثنانية.

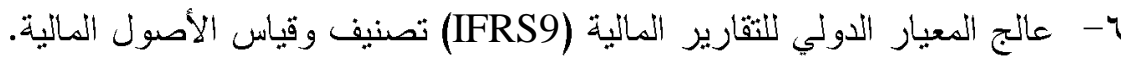

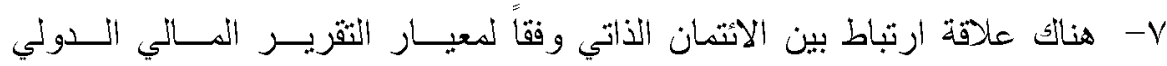

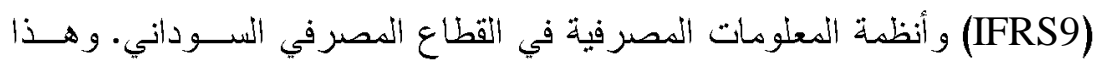
يعزز نتيجة الفرضية الثالثة. ^- أدى تطبيق متطنبات محاسبة التحوط وفقاً لمعيار (IFRS9) في القطاع المصرفي السوداني إلى التنأثير على أنظمة المعلومات المصرفية. وهذا يعزز نتيجة الفرضية

$$
\text { الز ابعة. }
$$

9- وجود العديد من التحديات التى تو اجه المصـارف السودانية عند التطبيــق الفعلــي لمتطلبات (IFRS9) ولعل أهمها، إسباءة منشآت الأعمال لاستخدام المعيار الجديد

(IFRS9) (لقلة خبرة الإدارة المالية بمتطلبات المعيار وعدم الجاهزية لتطبيقه.

ثانياً: التوصيات: بناءً على النتائج التي توصل إلتها (الباحث) فإنه يوصي بالآتي:

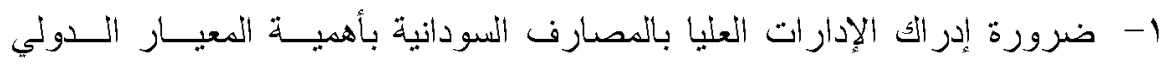

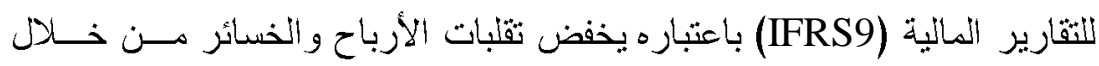
أنشطة التحوط الاقتصادي. ب- ضرورة تضافر الجهود لدى أدارات المصارف السودانية لتذيل التحديات المختلفة التى تعيق تطبيق (IFRS9) في البيئة السودانية.

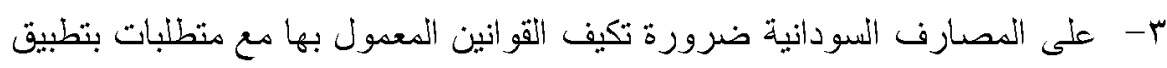
المعياز الدولي للتثارير المالية (IFRS9) بما ينسجم مع حاجة البيئة السودانية.

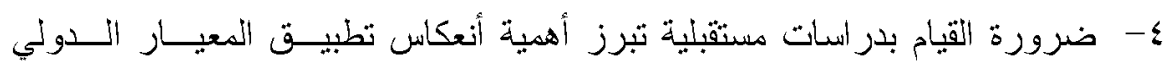

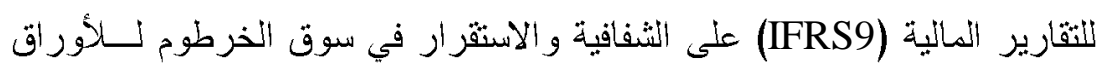
المالية ودوره في تعزيز تقة المستثرين في السوق. 


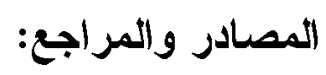

أولاً: المصادر والمراجع العربية:

- 1

• خضير كاظم حمود، هايل يعقوب فاخورب، إدارة الإتتاج والعمليات، عــان:

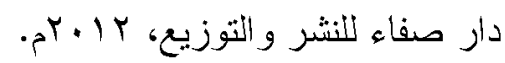

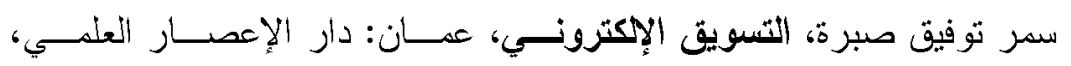

•

طارق طه، إدارة البنوك ونظم المعلومات المصـرفية، الانسـكندرية: منثــأة

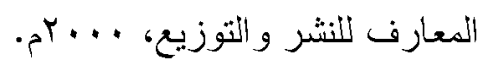

محمد أبو نصار، جمعة حميدات، معايير المحاسبة والإبلاغ المالي الدولية ولئي

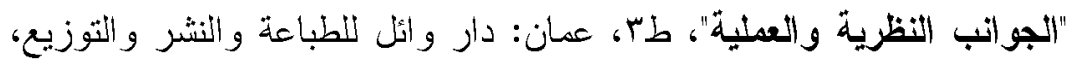

هحمد الصيرفي، المرجع المتكامل في الإدارة الإكترّونية للفــوارد البثــرية،

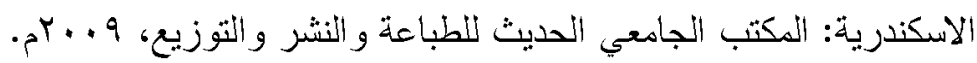

- ب

• إبر اهيم محمد علي الجزر اوي، نادية شاكر النعيمي، "تحليل الايتمان المصــرفي

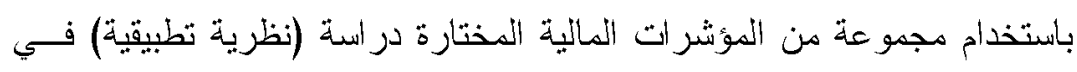

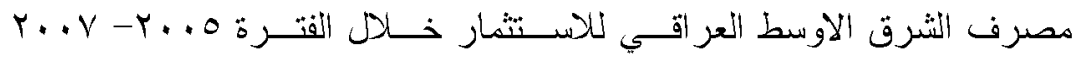

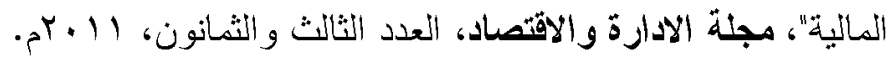

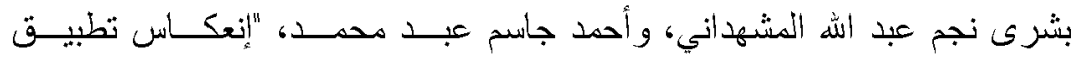

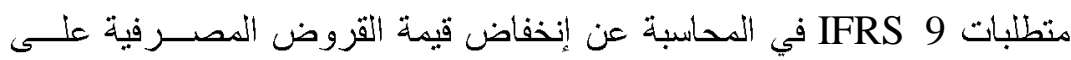

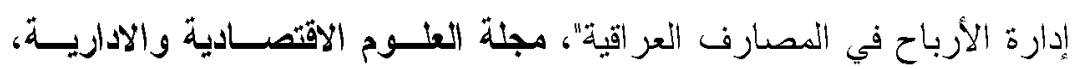

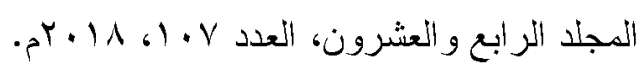

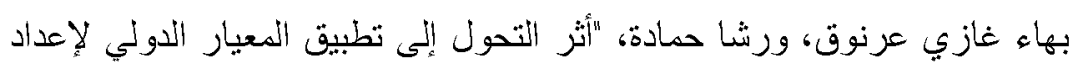

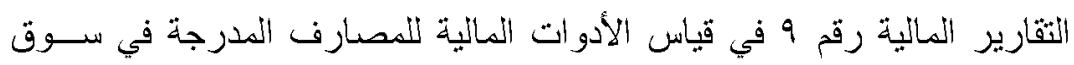

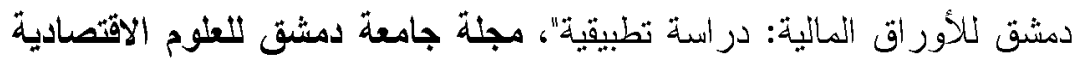

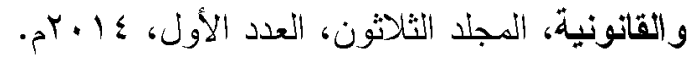

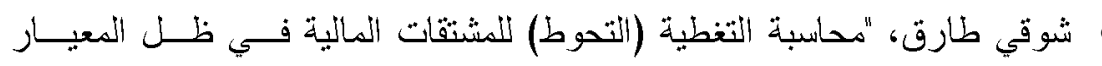

الدولي لإعداد التقارير المالية رقم IFRS9 الأدوات المالية مقارنة مع المعيـار 
الأمريكي SFAS133"، مجلة العلوم الاقتصادية وعلوم التسيير، العدد النسابع

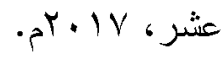

• صدالح علي أحمد محمد، ومحجوب عبد الله حامــد، "در اســة تحليليــة للآثــار

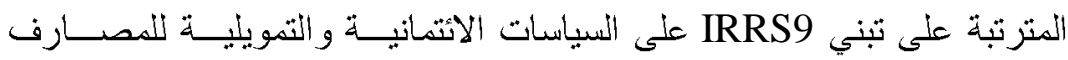

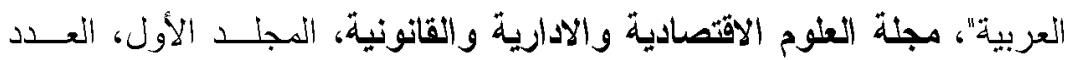

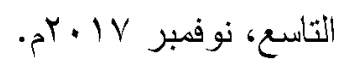
علاء علي أحمد حسين، "تأثئير تصنيف وقياس الاستثمار ات المالية وفقا لمنطلبات

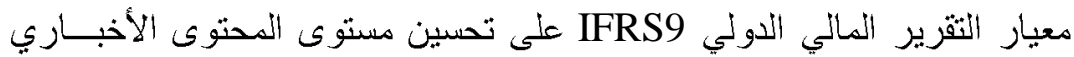

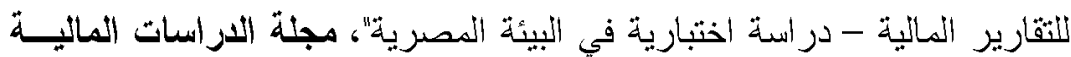

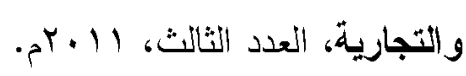
• فر اس إِسماعبل مسعود سقف الحيط، ومحمد فوزي شاكر شبيطة، "أثُر تطبيـق

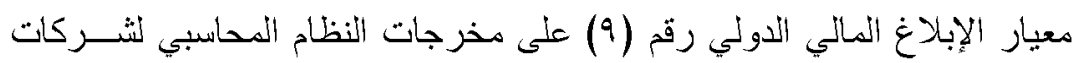
التأمين في الأردن"، مجلة الزرقاء للبحوث و الأراسات الإنسانية، الدجلد السابع،

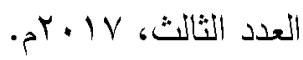

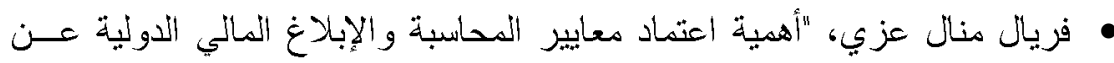

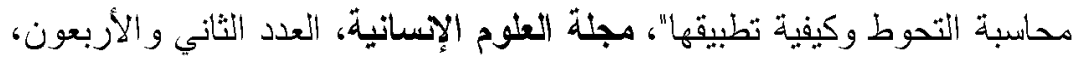
ديسمبر ك 1 • بام.

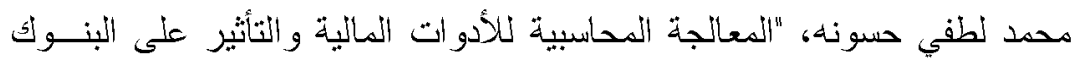

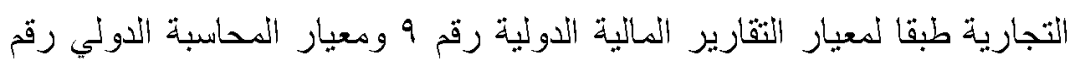

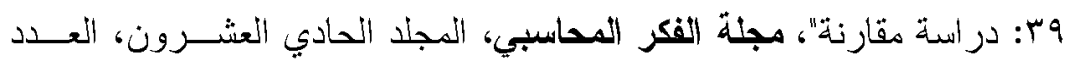

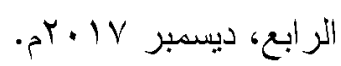

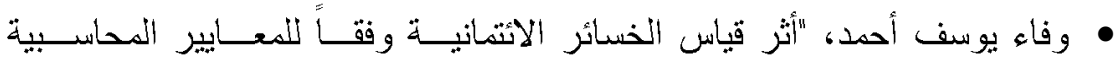

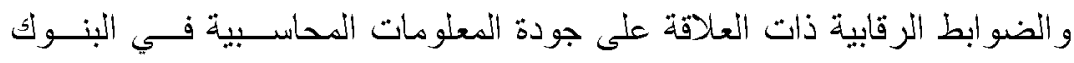

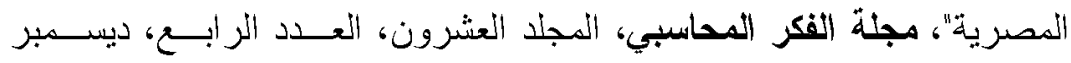

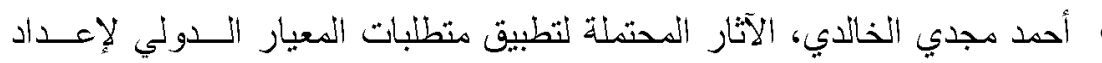

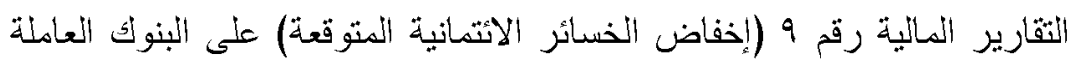

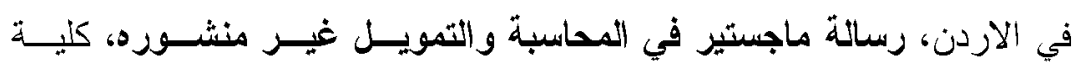

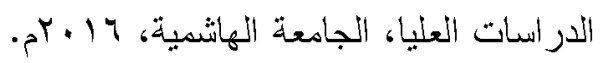


حسين ذيب، فعالية نظم المعلومات المصرفية في تسير حالات فثــل الاثتــــان:

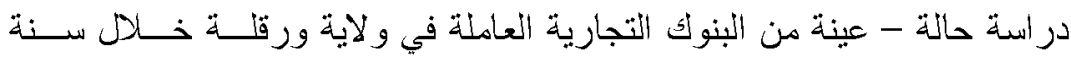

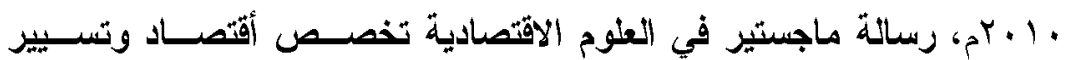

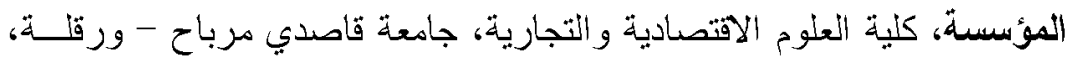
$.0 r+1 r$ محمد صبحي عبد الله الحميدي، أثر تطبيق معيار الإبلاغ المالي الدولي التاســع

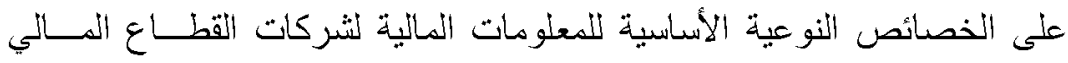

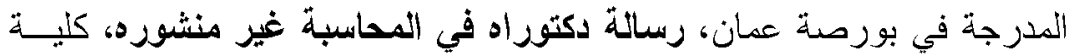

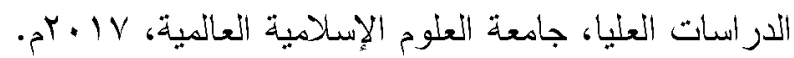

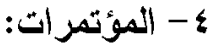

• أحمد قايد نور الدين، وهلايلي إِسلام، وبن زاف لبنى، توافق معيـار التقـارير

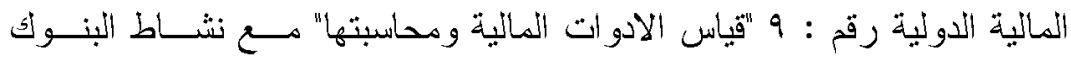
الاسلامية، بحث قدم في المؤتمر العلمي الدولي حول: دور المصارف الإسلامية

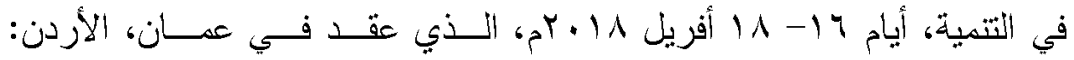

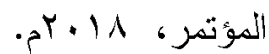

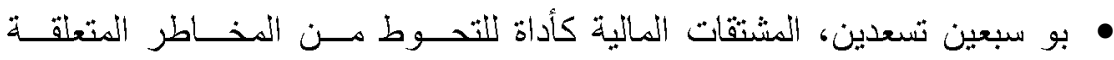
بالمعلومة المحاسبية والمالية، بحث قدم في الملتقي الاولي الأول بجامعة العقيد

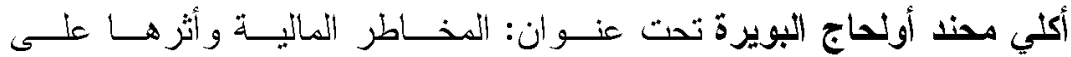

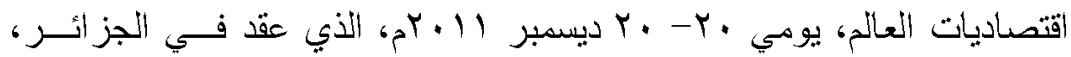

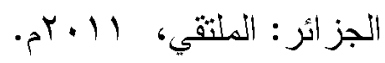

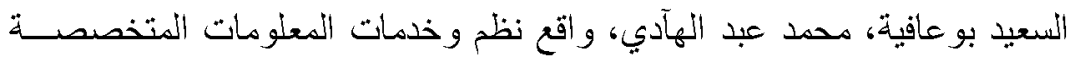

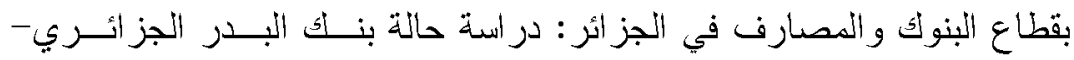

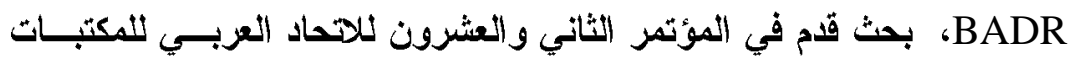

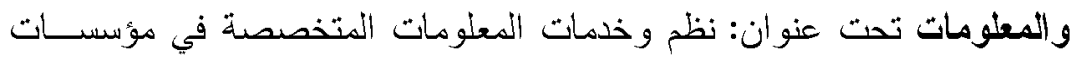

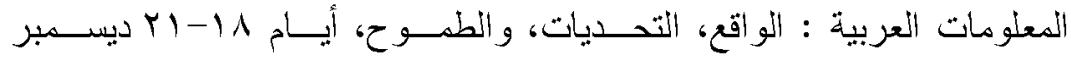

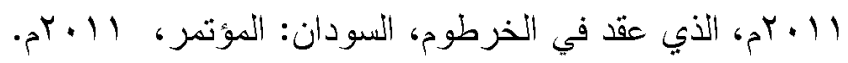

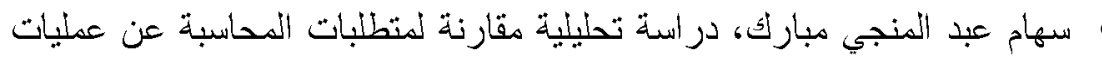

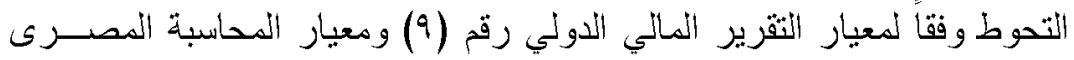

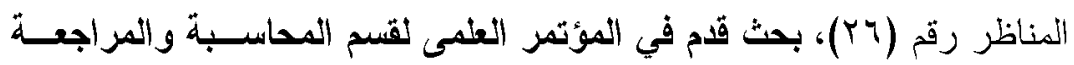

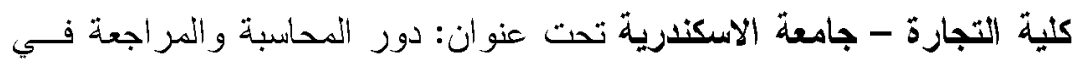




$$
\begin{aligned}
& \text { دعم التتمية الاقتصادية والاجتماعية في مصر، يومي Y- V مايو V ل آ ام، الذب }
\end{aligned}
$$

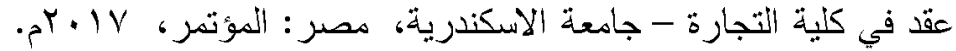

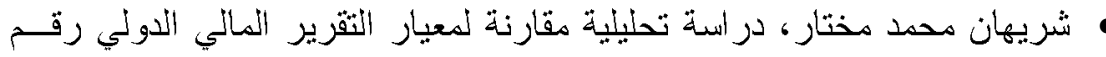

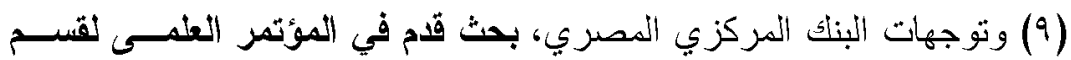

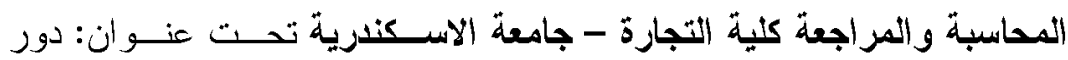

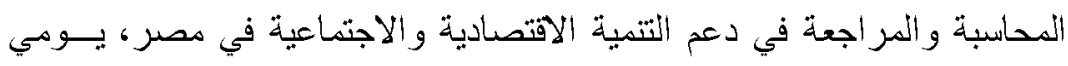

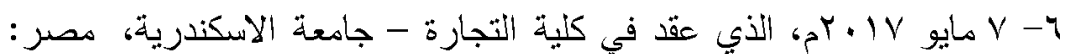

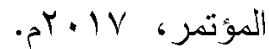

$$
\begin{aligned}
& \text { • هوام جمعة، وبر ايس نورة، توجهات المعايير الدولية نحو قياس القيمة العـادلـــة }
\end{aligned}
$$

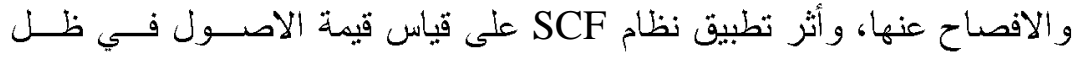

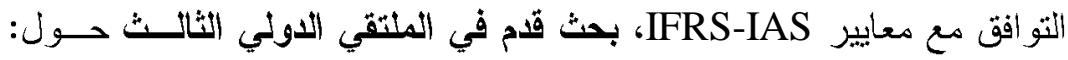

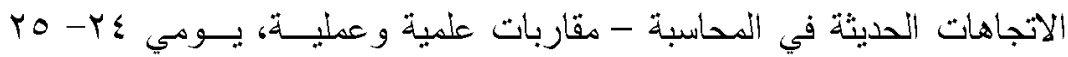

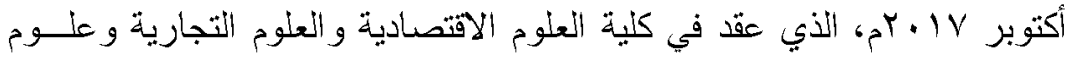

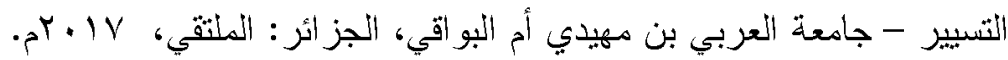

$$
\begin{aligned}
& \text { ثانياً: المصادر و المراجع الأجنبية: }
\end{aligned}
$$

(1) Periodicals and journals:

- Elshalom Endrias Essah, the impact of information system in Ethiopian commercial Banks. Journal of Information Systems Research and Innovation, Vol 10, No (3), 2016.

- Mojca Gornjak , Comparison of IAS 39 and IFRS 9: The Analysis of Replacement, International Journal of Management, Knowledge and Learning, Vol 6 , No (1),2017 .

$\bullet$ Analysis Of The Replacement Of International Financial Reporting Standard For Financial Instruments: IA's 39 versus FRS9, journal of Integrated Economy and Society: Diversity, Creativity, and Technology, Vol 16, No 18, 2018.

- Novotny-Farkas, Z. The Interaction of the IFRS 9 Expected Loss Approach with Supervisory Rules and Implications for Financial Stability. Journal of Accounting in Europe, Vol 13, No (2), 2016

- Petra Blažekova, The Impact Of FRS9 (increase in credit risk provisioning) on banks' regulatory capital, journal of Comenius Management Review , Vol 11 , No 2-3 , 2017 . 